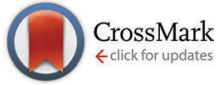

Cite this: New J. Chem., 2014, 38, 5226

Received (in Montpellier, France) 24th April 2014,

Accepted 1st August 2014

DOI: $10.1039 / c 4 n j 00654 b$

www.rsc.org/njc

\title{
Efficient synthesis of small-sized phosphonated dendrons: potential organic coatings of iron oxide nanoparticles $\dagger$
}

\author{
Antonio Garofalo, $\ddagger$ Audrey Parat, $\ddagger$ Catalina Bordeianu, Cynthia Ghobril, \\ Marie Kueny-Stotz, Aurélie Walter, Julien Jouhannaud, Sylvie Begin-Colin and \\ Delphine Felder-Flesch*
}

\begin{abstract}
We report herein the synthesis of biocompatible small-sized phosphonated monomers and dendrons used as functional coatings of metal oxide nanoparticles, more specifically superparamagnetic iron oxides (SPIOs) for magnetic resonance imaging (MRI) and therapy through hyperthermia. The molecules were engineered to modulate their size, their hydrophilic and/or biocompatible character (poly(amido)amine versus oligoethyleneglycol), the number of anchoring phosphonate groups (monophosphonate versus phosphonic tweezers) and the number of peripheral functional groups for further grafting of dyes or specific vectors. Such a library of hydrophilic phosphonic acids opens new possibilities for the investigation of dendronized nanohybrids as theranostics.
\end{abstract}

\section{Introduction}

Research on inorganic nanoparticles (NPs) is rapidly expanding with a large variety of applications, as well as strategies for their synthesis. ${ }^{1}$ Most often, surface modification of the NPs is critical, in particular to avoid their aggregation, make them dispersible in liquid media or derivatize them with functional end groups for further modification. Here again, the exceptional binding properties of phosphonic acids to oxide surfaces have attracted much attention and many examples of decorated magnetic metal oxide NPs using phosphonate terminated molecules have recently emerged in the literature. ${ }^{2}$

Many research groups worldwide are actively developing superparamagnetic iron oxide (SPIO) NPs with the emergence of a vast number of applications in health sciences, including for example combined in vivo magnetic resonance imaging (MRI) and optical imaging via multimodal NPs based on fluorescent probes conjugated to SPIO NPs, ${ }^{3}$ hyperthermic heating of tumours, ${ }^{4}$ and drug delivery. ${ }^{5}$ In this context, biofunctionalization of the NPs is most often required to avoid aggregation or rapid clearance by the Mononuclear Phagocyte System. ${ }^{6}$ For this purpose, appropriate coatings and especially surface modification using molecules derivatized with phosphonic

IPCMS UMR CNRS-UdS 7504, 23 rue du loess BP43, 67034 Strasbourg cedex 2, France. E-mail: Delphine.Felder@ipcms.unistra.fr; Fax: +33 (0)388107246;

Tel: $+33(0) 388107163$

$\dagger$ Electronic supplementary information (ESI) available. See DOI: 10.1039/ c4nj00654b

\$ These authors contributed equally to the work performed. acid groups are being developed. It is also worth noting that bisphosphonate anchors were found to bind more strongly to iron oxide NPs than monophosphonates, thus conferring them higher stability in water at physiological $\mathrm{pH}^{7}$

Among the most common routes to functional phosphonic acids for surface modification are the Michaelis-Arbuzov and Michaelis-Becker reactions, ${ }^{8}$ hydrophosphonylation with palladium (Tanaka's ${ }^{9}$ or Beletskaya's ${ }^{10}$ methods) or with nickel or copper, ${ }^{11}$ the Hirao cross-coupling, ${ }^{12}$ the phosphaMichael addition, ${ }^{13}$ and the Pudovik reaction ${ }^{14}$ starting from aldehydes. The Michaelis-Arbuzov reaction, ${ }^{15}$ also known as the Arbuzov reaction, is one of the most versatile reactions for the formation of $\mathrm{P}-\mathrm{C}$ bonds and consists of the reaction of a triester phosphite with an alkyl halide, resulting in the conversion of $\mathrm{P}$ (III) to a pentavalent phosphorus species. While elevated temperatures are required for the activation of the transformation, recent data have shown that for some specific substrates this reaction can be advantageously operated at room temperature in the presence of a suitable Lewis acid. ${ }^{16}$ Barney et al. $^{17}$ recently proposed a straightforward synthesis of benzyl or allyl phosphonates from the corresponding alcohols using triethylphosphite and zinc iodide. Benzyl phosphonates esters are usually prepared from benzyl halides and trialkylphosphite via an Arbuzov reaction and this procedure is a convenient alternative, although benzylic compounds bearing an electron-withdrawing group are much less reactive. Moreover, such synthetic methodology allows introducing the phosphonate group in the last steps of the synthesis, which is advantageous since the chromatographic 
purification of phosphonate-containing intermediates throughout the whole multistep synthesis is time-consuming.

Dendrimers or dendritic architectures ${ }^{18}$ are being developed for biomedical applications due to their precisely defined structure and composition, and high tuneable surface chemistry. ${ }^{19}$ A clear input is brought by the dendritic molecules as they are discrete and monodisperse entities in which size, hydrophilicity, molecular weight and biocompatibility can easily be tuned as a function of their generation. ${ }^{20}$ Furthermore, a dendritic shell allows versatile and reproducible polyfunctionalization at its periphery which could lead to, multimodal imaging probes through dye or fluorophore grafting, and theranostics through specific drug anchoring. Current studies show that small-sized dendrons may have an impressive future in the functionalization of magnetic nanoparticles $^{21}$ due to their highly controlled molecular structure and high tuneability leading to biocompatible, polyfunctional and water-soluble systems. Dendronized iron oxide nanoparticles using a phosphonate or hydroxamic acid anchor were shown to display very good colloidal properties and high relaxivity values. ${ }^{22}$ Such anchoring groups induced strong binding, ${ }^{23}$ and phosphonic anchors were demonstrated to preserve NPs' magnetic properties. ${ }^{24}$

We recently reported that a dendritic coating (Fig. 1) of magnetic metal oxide nanoparticles increases their effect on water proton relaxation times thus leading to optimized contrast enhancement capacities in MRI. ${ }^{25}$

Therefore, we managed to prepare a library of functional dendritic phosphonic acids either fully PEGylated (Part I) or derived from the poly(amido)amine (PAMAM) family (Part II). In both parts, the generation, the OEG chain length and the number of phosphonic anchors (mono-phosphonate or bisphosphonate tweezers) were varied. Such a library of functional hydrophilic phosphonic acids opens new possibilities for the investigation of dendronized nanohybrids as possible theranostics (Scheme 1).

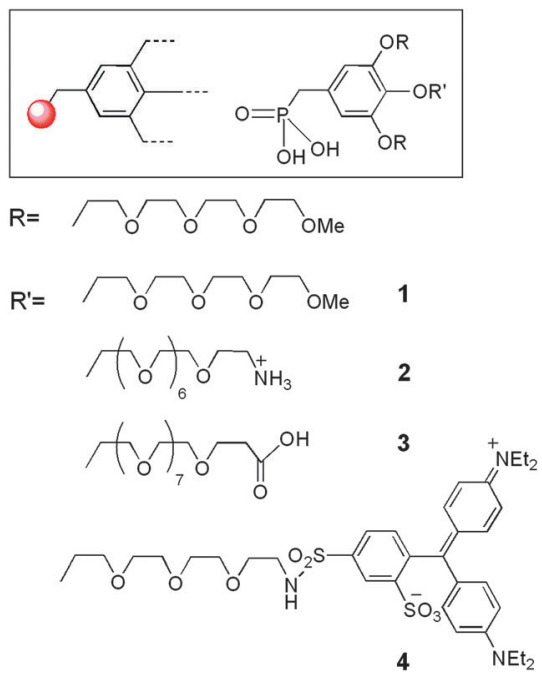

Fig. 1 Structure of phosphonic acid derivatives previously described. ${ }^{26}$

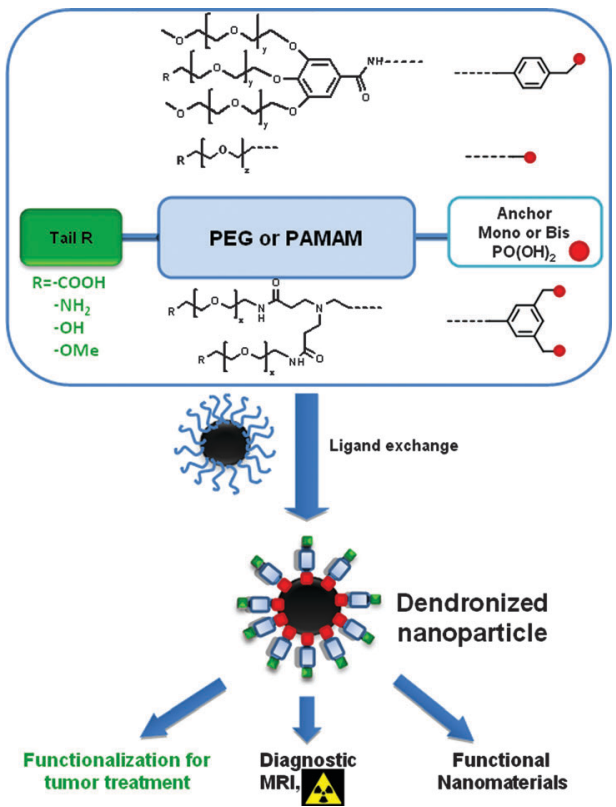

Scheme 1 General structure of synthesized compounds.

\section{Results and discussion}

\section{Part I: PEGylated monomers}

Synthesis of mono-ethylphosphonate. We have previously developed the synthesis of first generation monophosphonate oligoethylene glycol (OEG) gallate dendrons ( $\left.\mathrm{G}_{1}-\mathrm{P}_{1}-\mathrm{OEG}\right) \mathbf{1 - 4}$ (Fig. 1) bearing a longer functionalized OEG chain in the para position for further grafting of biomolecules. ${ }^{26}$ These smallsized monomers were obtained from the key intermediate 12 which was obtained in six steps with a $25 \%$ overall yield (Scheme 2). First, para-benzylated methyl gallate 6 and tosylated tetraethyleneglycol monomethyl ether $\mathbf{5}$ were obtained in good yields from the commercially available methyl gallate and tetraethyleneoxide monomethyl ether, respectively, following a reported one-step procedure. ${ }^{27} \mathrm{~A}$ Williamson etherification between 5 and 6 in acetone at $60{ }^{\circ} \mathrm{C}$, in the presence of potassium carbonate $\left(\mathrm{K}_{2} \mathrm{CO}_{3}\right)$ and potassium iodide (KI), allowed the preparation of ester 7 in $75 \%$ yield. Protected ethyl phosphonate $\mathbf{1 1}$ was obtained following a three-step sequence: (i) reduction of the ester function by lithium aluminium hydride $\left(\mathrm{LiAlH}_{4}\right)$ to obtain benzylic alcohol 9 in $90 \%$ yield, (ii) treatment of $\mathbf{9}$ with thionyl chloride $\left(\mathrm{SOCl}_{2}\right)$ to yield benzyl chloride 10 (70\%) and (iii) refluxing 10 at $160{ }^{\circ} \mathrm{C}$ in triethyl phosphate $\left(\mathrm{P}(\mathrm{OEt})_{3}\right)$ to prepare para-protected ethyl phosphonate 11 (85\%). Finally, phenol deprotection was achieved by hydrogenolysis in the presence of palladium activated on carbon (Pd/C) (10\%) which led, after overnight stirring, to ethyl phosphonate 12 in $96 \%$ yield.

Finally, monomers 1-4 (Fig. 1) were obtained after deprotection of the phosphonate esters with a large excess of trimethylsilyl bromide (TMSBr). ${ }^{21}$

The synthesis of ethyl phosphonate 15 displaying an ethylamine linker in the para-position is highlighted in Scheme 3. The compound was obtained in 4 steps with $54 \%$ overall yield. 


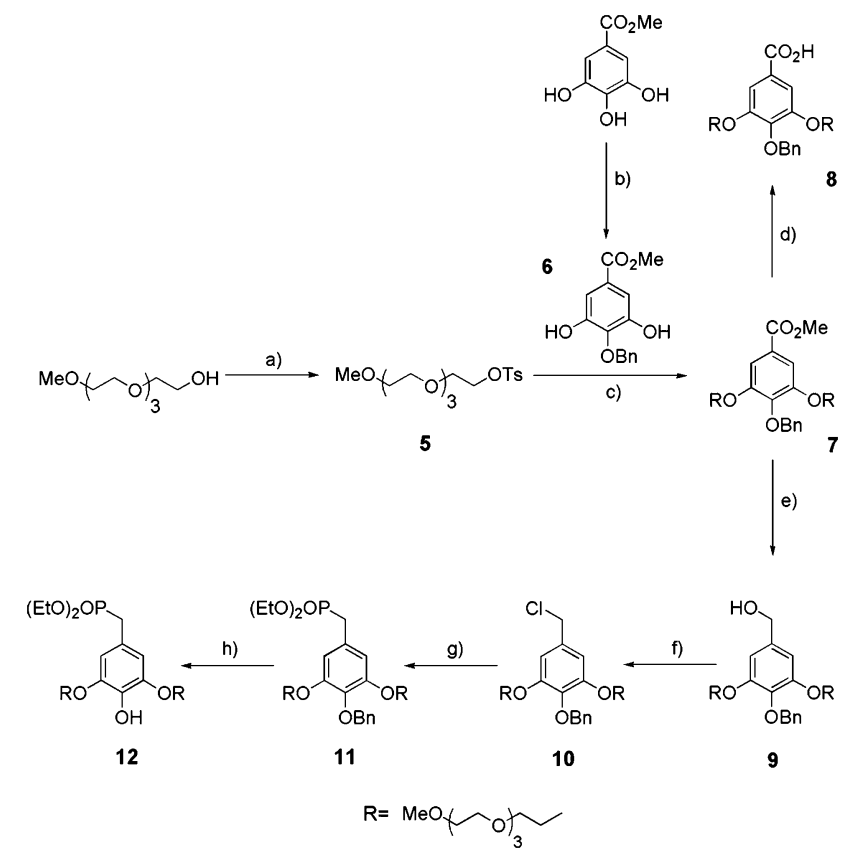

Scheme 2 Synthesis of mono-ethylphosphonate anchor 12 . (a) $\mathrm{TsCl}$, $\mathrm{NaOH}, \mathrm{THF} / \mathrm{H}_{2} \mathrm{O}, \mathrm{rt}, 24 \mathrm{~h}, 94 \%$; (b) benzyl bromide, $\mathrm{KHCO}_{3}, \mathrm{KI}, \mathrm{DMF}$, $30{ }^{\circ} \mathrm{C}, 4 \mathrm{~d}, 70 \%$; (c) $\mathrm{K}_{2} \mathrm{CO}_{3}, \mathrm{Kl}$, acetone, reflux, $24 \mathrm{~h}, 75 \%$; (d) $\mathrm{NaOH}, \mathrm{MeOH} /$ $\mathrm{H}_{2} \mathrm{O}$, reflux, $2 \mathrm{~h}, 90 \%$; (e) $\mathrm{LiAlH}_{4} 1 \mathrm{M}$ in THF, THF, rt, $1 \mathrm{~h}, 90 \%$; (f) $\mathrm{SOCl}_{2}$, $\mathrm{CH}_{2} \mathrm{Cl}_{2}$, reflux, 2 h, 70\%; (g) $\mathrm{P}(\mathrm{OEt})_{3}, 160{ }^{\circ} \mathrm{C}, 3$ h, 85\%; (h) $\mathrm{Pd} / \mathrm{C} 10 \%$, $\mathrm{H}_{2}, \mathrm{EtOH}, \mathrm{rt}, 16 \mathrm{~h}, 96 \%$.

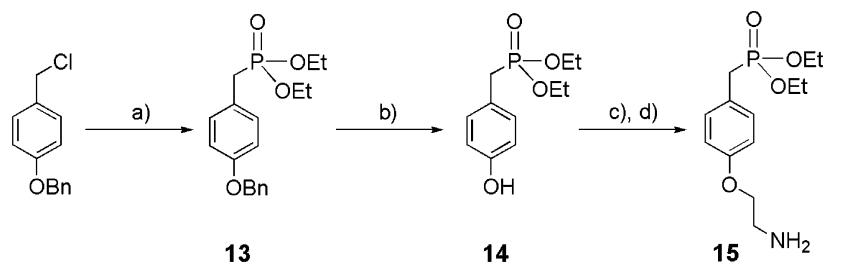

Scheme 3 Synthesis of mono-ethylphosphonate anchor 15. (a) $\mathrm{P}(\mathrm{OEt})_{3}$, $160{ }^{\circ} \mathrm{C}, 3$ h, 92\%; (b) $\mathrm{Pd} / \mathrm{C} \mathrm{10 \% ,} \mathrm{H}_{2}, \mathrm{EtOH}, \mathrm{rt}, 16 \mathrm{~h}, 92 \%$; (c) Boc-2bromoethylamine, $\mathrm{K}_{2} \mathrm{CO}_{3}, \mathrm{Kl}$, acetone, reflux, $16 \mathrm{~h}$; (d) $\mathrm{TFA}, \mathrm{CH}_{2} \mathrm{Cl}_{2}, \mathrm{O}^{\circ} \mathrm{C}$ to rt, 16 h, $94 \%$.

First, 4-(benzyloxy) benzyl chloride reacted under reflux with $\mathrm{P}(\mathrm{OEt})_{3}$ to yield 13 (92\%). Phenol 14 was obtained after hydrogenolysis in the presence of $\mathrm{Pd} / \mathrm{C}(10 \%)$, and was next engaged in an etherification reaction in the presence of Boc-2-bromoethylamine. Subsequent treatment with trifluoroacetic acid (TFA) yielded 15 (94\%).

Synthesis of bis-amino mono-ethylphosphonate. The synthetic route of the key intermediate $\mathbf{1 8}$ for the preparation of dendritic ethyl phosphonate is reported in Scheme 4. Benzyl bromide 16 was obtained in $84 \%$ yield from the commercially available 3,5-dihydroxybenzyl alcohol after its activation with triphenyl phosphine $\left(\mathrm{PPh}_{3}\right)$ and tetrabromomethane $\left(\mathrm{CBr}_{4}\right)$. Compound 16 was immediately converted to its corresponding ethyl phosphonate 17 after refluxing for 2 hours in $\mathrm{P}(\mathrm{OEt})_{3}$. An etherification reaction between 17 and Boc-2-bromoethylamine, followed by the deprotection of the two amine functions in the presence of TFA, provided 18 as a ditrifluoroacetate salt (59\% yield over 2 steps).

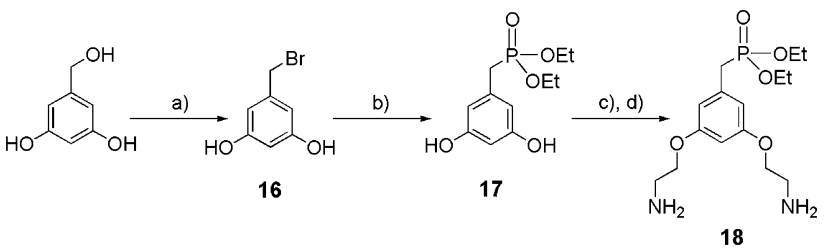

Scheme 4 Synthesis of mono-ethylphosphonate anchor 18. (a) $\mathrm{CBr}_{4}$, $\mathrm{PPh}_{3}, \mathrm{THF}, 0{ }^{\circ} \mathrm{C}$ at rt, $2 \mathrm{~h}, 88 \%$; (b) $\mathrm{P}(\mathrm{OEt})_{3}, 160{ }^{\circ} \mathrm{C}, 2 \mathrm{~h}, 75 \%$; (c) Boc-2bromoethylamine, $\mathrm{K}_{2} \mathrm{CO}_{3}, \mathrm{Kl}$, acetone, reflux, $16 \mathrm{~h}, 65 \%$; (d) TFA, $\mathrm{CH}_{2} \mathrm{Cl}_{2}$, $0{ }^{\circ} \mathrm{C}$ to rt, $16 \mathrm{~h}, 95 \%$.
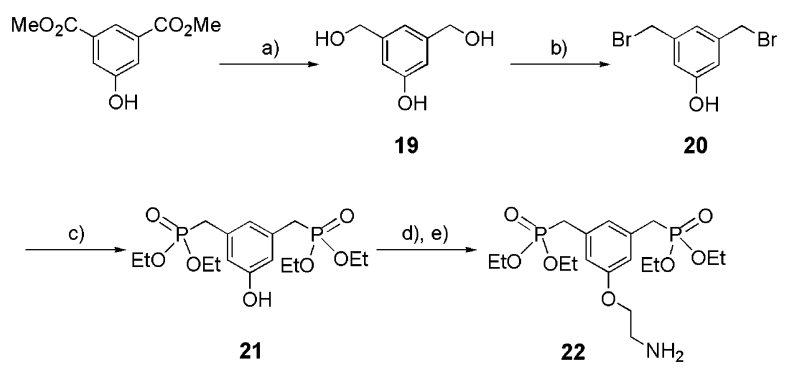

Scheme 5 Synthesis of bis-ethylphosphonate anchor 22. (a) $\mathrm{LiAlH}_{4} 1 \mathrm{M}$ in THF, THF, reflux, 3 h, 94\%; (b) HBr in acetic acid 30\%, acetic acid, rt, $24 \mathrm{~h}$, $96 \%$; (c) $\mathrm{P}(\mathrm{OEt})_{3}, 160{ }^{\circ} \mathrm{C}, 2 \mathrm{~h}, 95 \%$; (d) Boc-2-bromoethylamine, $\mathrm{K}_{2} \mathrm{CO}_{3}, \mathrm{Kl}$, acetone, reflux, $16 \mathrm{~h}, 76 \%$; (e) TFA, $\mathrm{CH}_{2} \mathrm{Cl}_{2}, 0{ }^{\circ} \mathrm{C}$ to rt, $16 \mathrm{~h}, 88 \%$.

Synthesis of mono-amino bis-ethylphosphonate tweezers. The synthesis of tweezers 22 is detailed in Scheme 5. Its precursor 21 was obtained in three steps (reduction, bromination, and phosphorylation), with $86 \%$ overall yield, starting from the commercially available dimethyl-5-hydroxyisophthalate. Amine 22 was then easily prepared from $\mathbf{2 1}$ by Williamson etherification in the presence of Boc-2-bromoethylamine followed by the treatment with TFA ( $67 \%$ over 2 steps).

Synthesis of bis-amino bis-ethylphosphonate tweezers. Bis-ethyl phosphonate $\mathbf{2 6}$ was obtained following the synthetic route depicted in Scheme 6. Synthesis of the carboxylic acid intermediate $\mathbf{2 4}$ was accomplished in two steps starting from 3,5-dihydroxybenzoic acid methyl ester: etherification in acetone with Boc-2-bromoethylamine under basic conditions (23) (65\%) followed by saponification by sodium hydroxide $(\mathrm{NaOH})(86 \%)$. A peptide coupling between amine 22 and acid 24 in the

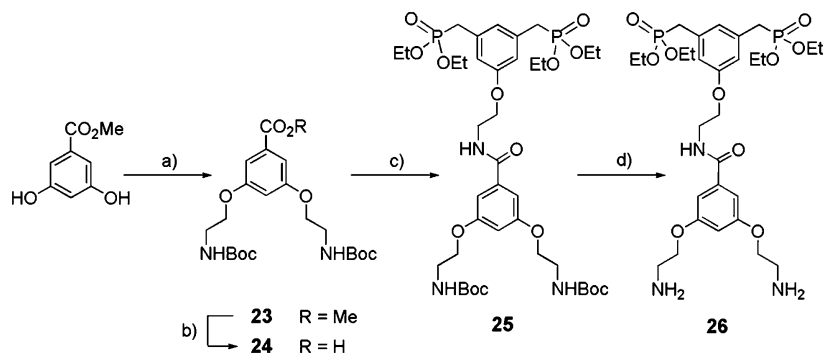

Scheme 6 Synthesis of bis-ethylphosphonate anchor 26. (a) Boc-2bromoethylamine, $\mathrm{K}_{2} \mathrm{CO}_{3}, \mathrm{Kl}$, acetone, reflux, $16 \mathrm{~h}, 65 \%$; (b) $\mathrm{NaOH}$, $\mathrm{MeOH} / \mathrm{H}_{2} \mathrm{O}$, reflux, $2 \mathrm{~h}, 86 \%$; (c) 22, BOP, DIPEA, $\mathrm{CH}_{2} \mathrm{Cl}_{2}, \mathrm{rt}, 24 \mathrm{~h}, 65 \%$; (d) TFA, $\mathrm{CH}_{2} \mathrm{Cl}_{2}, \mathrm{O}{ }^{\circ} \mathrm{C}$ to rt, $16 \mathrm{~h}, 98 \%$. 

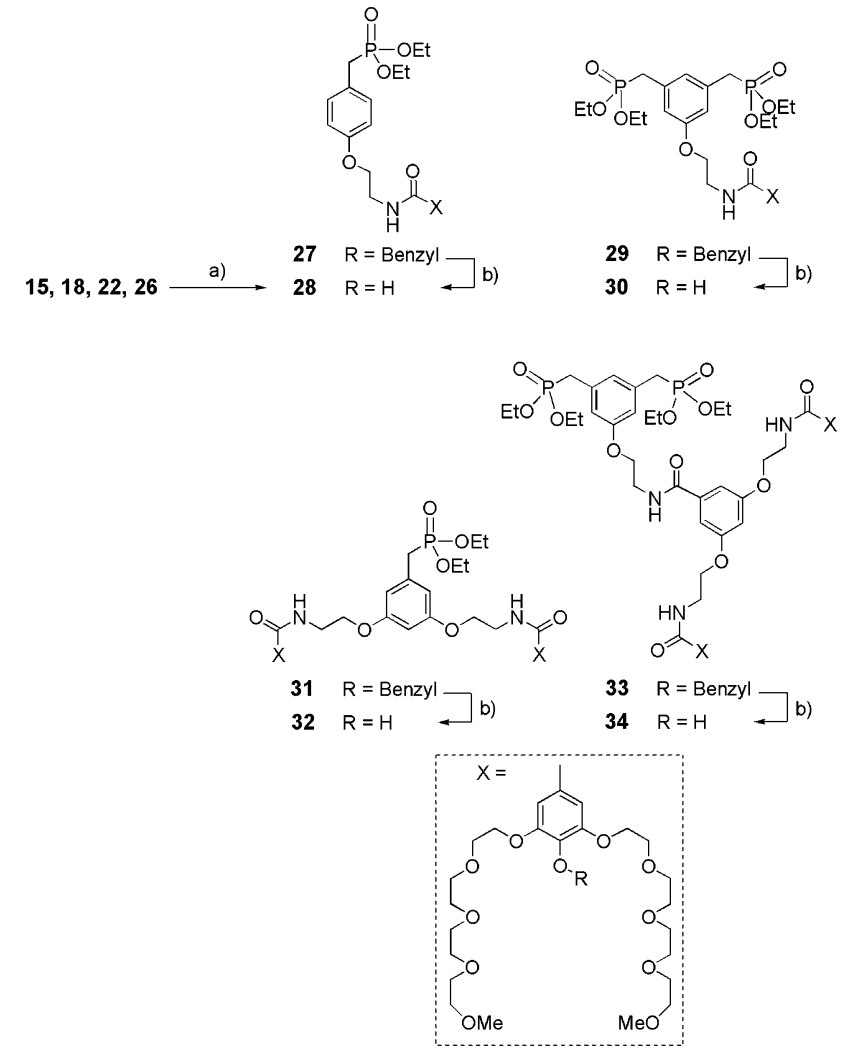

Scheme 7 Synthesis of dendritic ethylphosphonates 28-34. (a) 8, BOP, DIPEA, $\mathrm{CH}_{2} \mathrm{Cl}_{2}, \mathrm{rt}, 24 \mathrm{~h},(70-85 \%)$; (b) $\mathrm{Pd} / \mathrm{C} 10 \%, \mathrm{H}_{2}$, EtOH, rt, 16 h, (75-85\%)

presence of (benzotriazol-1-yloxy)tris(dimethylamino)phosphonium hexafluorophosphate (BOP) and $N, N$-diisopropylethylamine (DIPEA) led to 25 with $65 \%$ yield. Finally, Boc removal by TFA yielded 26 as a di-trifluoroacetate salt (98\%).

Synthesis of dendritic mono- and bis-ethylphosphonates. The synthetic route to phenolic intermediates $28,30,32,34$ is described in Scheme 7. Amines 15, 18, 22 or 26 underwent a peptide coupling type reaction with carboxylic acid 8 (obtained by saponification of 7 with $\mathrm{NaOH}$, Scheme 2) in the presence of BOP and DIPEA to obtain benzylated compounds 27, 29, 31 or $33(70-85 \%)$ respectively. Finally, hydrogenolysis in the presence of $\mathrm{Pd} / \mathrm{C}$ led to the corresponding ethyl phosphonates $28,30,32$ or 34 , respectively, with 75 to $85 \%$ yield.

Synthesis of $\mathrm{COOH}$-functionalized dendritic phosphonic acids. Refluxing in concentrated hydrochloric acid $(\mathrm{HCl})$ is an easy route for conversion of phosphonate esters into their acid analogues. However, for sensitive products requiring milder reaction conditions, McKenna's method ${ }^{28}$ using bromotrimethylsilane (TMSBr) remains an efficient method which allows the obtention of trimethylsilyl phosphonate ester intermediates that hydrolyze in situ into phosphonic acids, in protic medium (water or alcohol).

In order to achieve the synthesis of phosphonic acids 40-43 bearing a long functionalized oligoethylene glycol chain in the para position, the first step was the synthesis of the common intermediate 35 (Scheme 8), which was obtained in good yield starting from the commercially available hydroxy-dPEG ${ }^{\mathbb{R}}{ }_{8}-t$-butylester. ${ }^{29}$

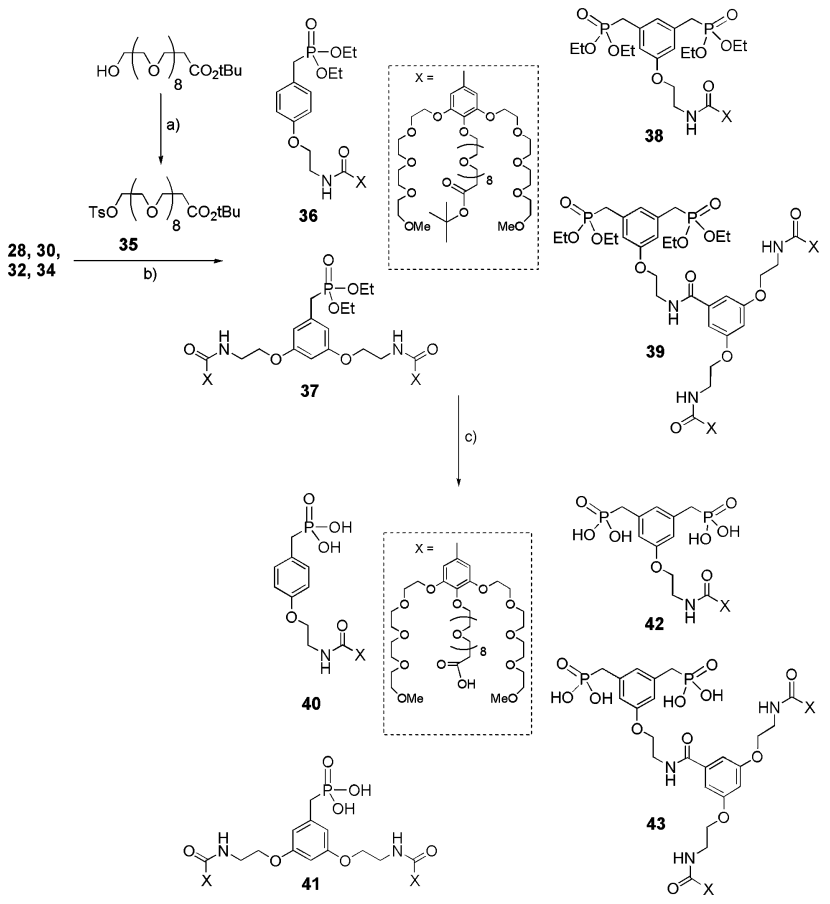

Scheme 8 Synthesis of dendritic and functional phosphonic acids 40-43. (a) $\mathrm{TsCl}, \mathrm{NEt}_{3}, \mathrm{CH}_{2} \mathrm{Cl}_{2}, \mathrm{rt}, 24 \mathrm{~h},(85 \%)$; (b) 35, $\mathrm{K}_{2} \mathrm{CO}_{3}, \mathrm{Kl}$, acetone, reflux, $16 \mathrm{~h}$, (70-90\%); (c) TMSBr, $\mathrm{CH}_{2} \mathrm{Cl}_{2}, \mathrm{rt}, 16 \mathrm{~h}$, (85-95\%).

35 then underwent a Williamson reaction with ethylphosphonates $28,30,32$ or 34 in acetone at $60{ }^{\circ} \mathrm{C}$ in the presence of $\mathrm{K}_{2} \mathrm{CO}_{3}$ and KI to yield the corresponding dendritic ethyl phosphonates 36-39 in $70-90 \%$ yield. Treatment of $36,37,38$ or 39 with a large excess of TMSBr generated a phosphonic acid function at the focal point and converted the terminal tert-butyl ester group into its corresponding carboxylic acid. This step allowed the obtention of compounds $40-43$ in $85-95 \%$ yields.

Synthesis of dye-functionalized dendritic phosphonic acids via click chemistry. Phenols 12 and 28, 30, 32, 34 were subjected to an etherification reaction in acetone at reflux in the presence of propargyl bromide (Scheme 9).

The corresponding acetylenic derivatives 44-48 were engaged in click reactions with azide-derivatized Patent Blue VF Dye (Scheme 10).

Patent Blue VF was first converted into sulfonyl chloride 49 by treatment with phosphoryl chloride $\left(\mathrm{POCl}_{3}\right)$ for 3 days and was used without further purification. The reaction between the commercially available OEGylated azide and sulfonyl chloride 49 led to the preparation of sulfonamide 50 in a moderate $50 \%$ yield. The click reaction between propargyl derivatives 44-48, and 50, in the presence of copper(II) sulphate $\left(\mathrm{CuSO}_{4} \cdot 5 \mathrm{H}_{2} \mathrm{O}\right)$ and sodium ascorbate, gave ethyl phosphonates 51, 53, 55, 57, 59 in $50-85 \%$ yields, which were then deprotected with an excess of TMSBr to yield their phosphonic acid derivatives 52, $\mathbf{5 4}, \mathbf{5 6}, \mathbf{5 8}$, and 60 (90-95\% yield).

\section{Part II: PAMAM-OEG dendrons}

Another design of our small-size dendrons was based on a small poly(amido)amine structure. Precisely, alkyne monomer 


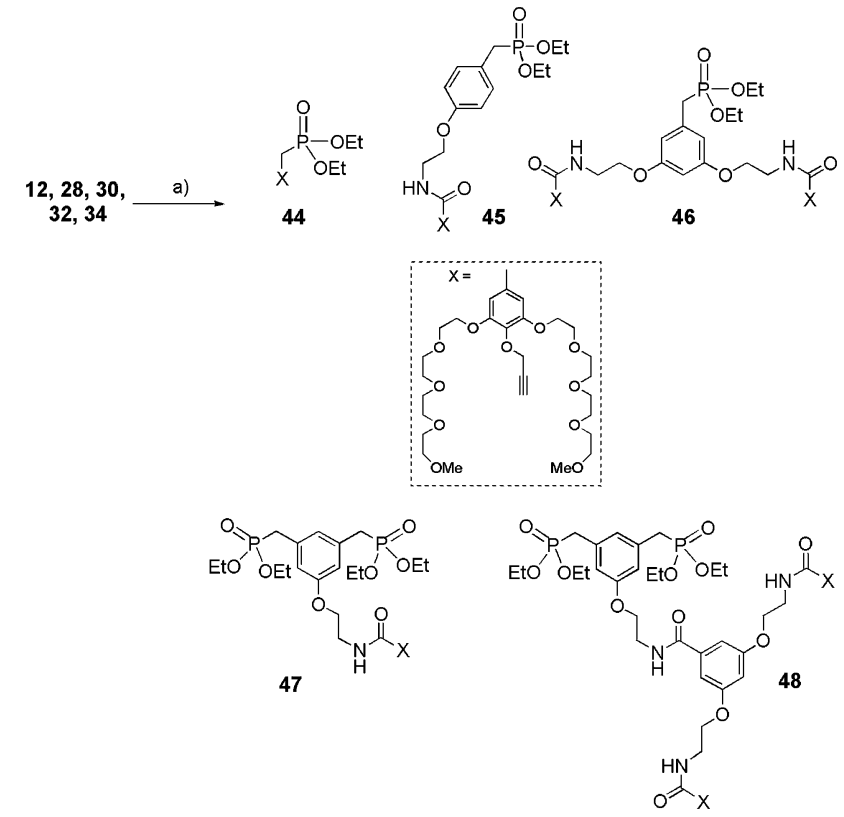

Scheme 9 Synthesis of acetylenic derivatives 44 to 48. (a) Propargyl bromide in xylene $80 \%, \mathrm{~K}_{2} \mathrm{CO}_{3}, \mathrm{Kl}$, acetone, reflux, $2 \mathrm{~h},(80-90 \%)$.

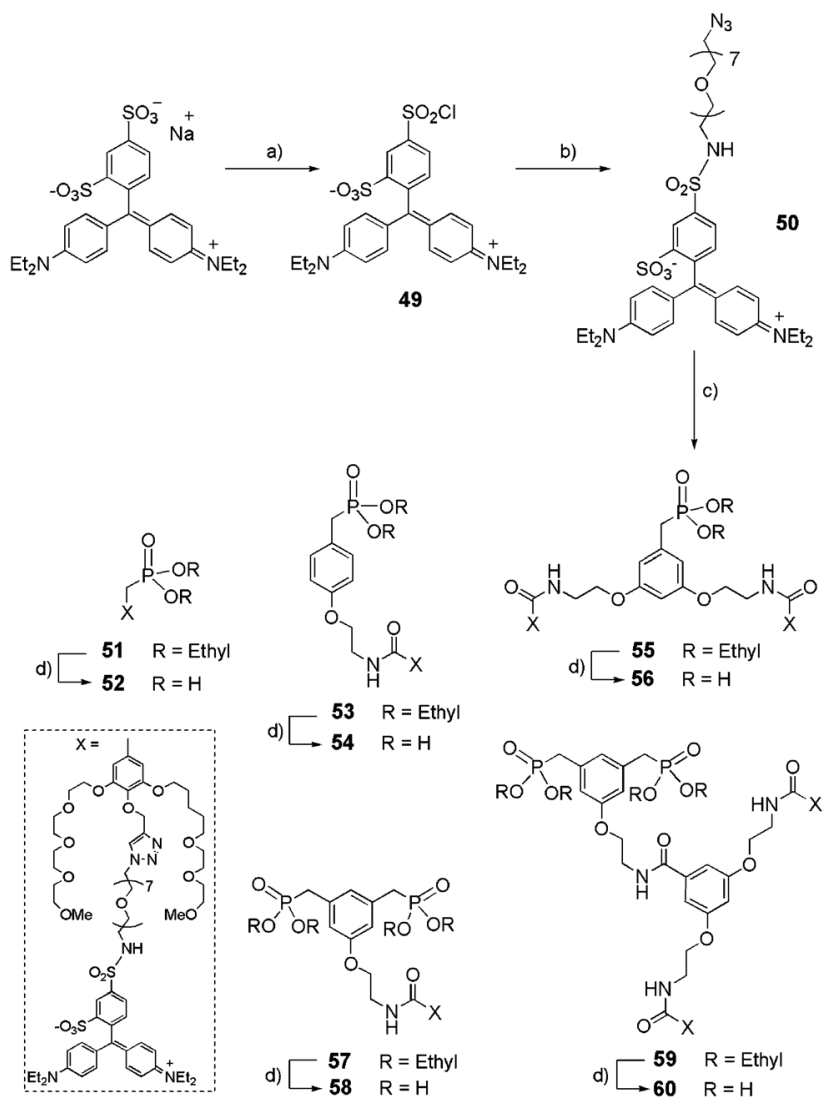

Scheme 10 Synthetic route to dye-functionalized dendritic phosphonic acids 52, 54, 56, 58 and 60. (a) Patent Blue VF, POCl, rt, 3 d, 90\%; (b) azido-dPEG ${ }^{\mathrm{TM}}{ }_{7}$-amine, $\mathrm{NEt}_{3}, 4$-DMAP, $\mathrm{CH}_{2} \mathrm{Cl}_{2} / \mathrm{DMF}, 0{ }^{\circ} \mathrm{C}$ to rt, $16 \mathrm{~h}$, $50 \%$; (c) 44, 45, 46, 47 or $48, \mathrm{CuSO}_{4} \cdot 5 \mathrm{H}_{2} \mathrm{O}$, sodium ascorbate, DMSO/ $\mathrm{H}_{2} \mathrm{O}, \mathrm{rt}, 16 \mathrm{~h},(50-85 \%)$; (d) $\mathrm{TMSBr}, \mathrm{CH}_{2} \mathrm{Cl}_{2}, \mathrm{rt}, 16 \mathrm{~h},(90-95 \%)$.

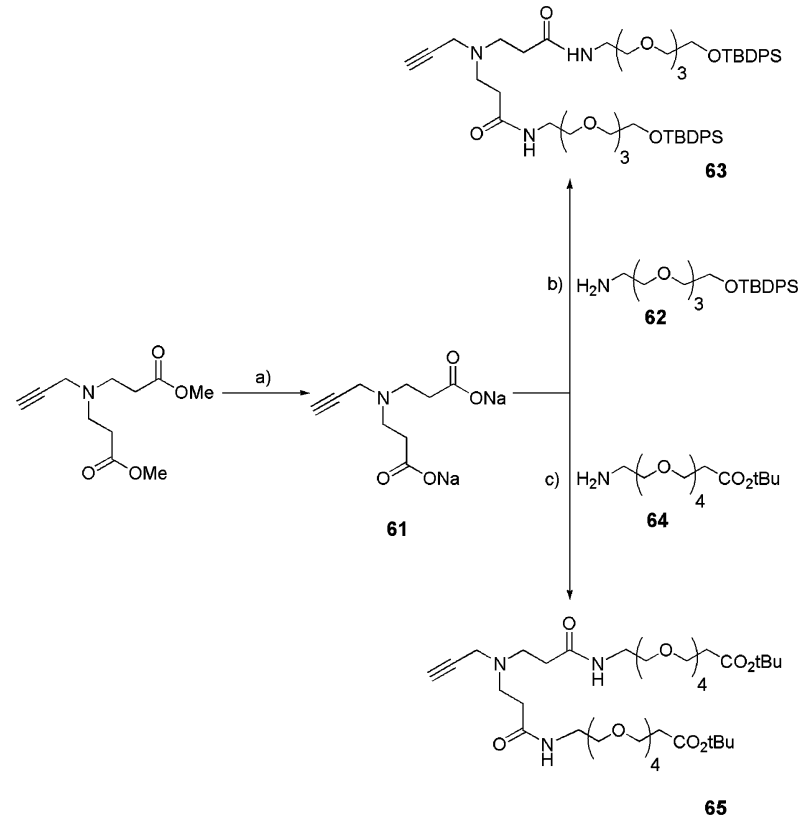

Scheme 11 Introduction of functional OEG chains into a poly(amido)amine monomer. ${ }^{22 C}$ (a) TMSONa $1 \mathrm{M}, \mathrm{CH}_{2} \mathrm{Cl}_{2}, \mathrm{rt}, 16 \mathrm{~h}$, quant; (b) $\mathrm{N}, \mathrm{N}^{\prime}-$ diisopropylcarbodiimide (DIC), hydroxybenzotriazole (HOBt), DMF, $60{ }^{\circ} \mathrm{C}$, 24 h, 70\%; (c) 1-ethyl-3-(3-dimethylaminopropyl)carbodiimide (EDCl), HOBt, DIPEA, $\mathrm{CH}_{3} \mathrm{CN}, \mathrm{rt}, 16 \mathrm{~h}, 67 \%$.

61 was synthesized following a reported procedure (Scheme 11). ${ }^{30}$ After deprotection of the two methyl esters by sodium trimethylsilanolate (TMSONa), functionalized OEG chains (62 or 64) were introduced into the monomer by a peptide coupling reaction as shown in Scheme 11 to yield bifunctional acetylenic conjugates (63 or 65). The OEG chains were chosen for their tunable length and possible derivatization.

In parallel, two azide-derivatized ethylphosphonate precursors displaying one (67) or two (72) phosphorus anchors were synthetized (Scheme 12). The mono-ethylphosphonate precursor 67 was obtained in a two-step sequence starting from commercially available 1,4-bis(chloromethyl)benzene whereas the bis-ethylphosphonate anchor $\mathbf{7 2}$ was obtained in a four-step procedure starting from methyl-3,5-dibromomethylbenzoate $\mathbf{6 8}^{22 c, 30,31}$ (Scheme 12).

Acetylenic PAMAM monomers 63 and 65 underwent the click reaction catalyzed by $\mathrm{Cu}(\mathrm{II}) \mathrm{SO}_{4} \cdot 5 \mathrm{H}_{2} \mathrm{O}$ in the presence of sodium ascorbate as the reducing agent with either azide 67 or 72 (Scheme 13) to yield mono-(73) or bis-ethylphosphonates $\mathbf{7 4}$ and 75.

\section{Part III: linear phosphonates}

Linear aromatic bis-ethyl phosphonates were successfully prepared via the click reaction (Schemes 14 and 15). ${ }^{32}$ Discrete short (76) or long (78) ${ }^{33}$ alkyne-derivatized OEG arms were obtained quantitatively starting from their alcohol counterparts in the presence of propargylbromide and potassium tert-butoxide ( $t \mathrm{BuOK})$ in THF. They were then reacted with azide $\mathbf{7 2}$ following the same procedure described for 74-75 (Scheme 13) to yield linear bis-ethyl phosphonates 79 and 80, respectively (Scheme 14). 


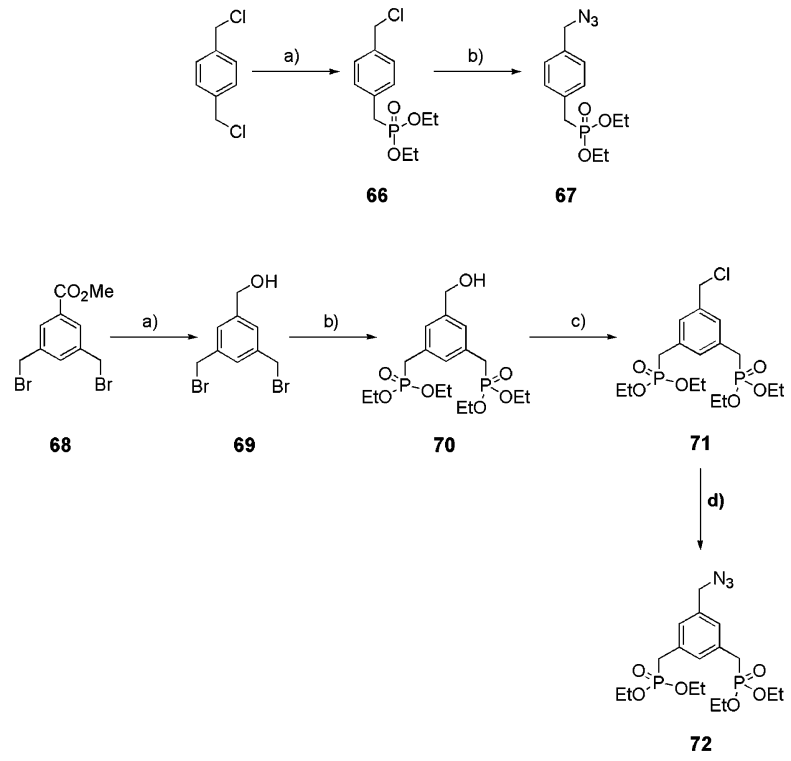

Scheme 12 Synthesis of mono- and bis-ethylphosphonate azide precursors 67 and 72. For precursor 67: (a) P(OEt) $3,120{ }^{\circ} \mathrm{C}, 2$ h, 48\%; (b) $\mathrm{NaN}_{3}$ $\mathrm{CH}_{3} \mathrm{CN}$, reflux, $16 \mathrm{~h}, 95 \%$. For precursor 72: (a) DIBALH, toluene, $3 \mathrm{~h}, 0{ }^{\circ} \mathrm{C}$, 90\%; (b) $\mathrm{P}(\mathrm{OEt})_{3}, 2 \mathrm{~h}, 140{ }^{\circ} \mathrm{C}$, quant; (c) $\mathrm{SOCl}_{2}, \mathrm{CHCl}_{3}, 1 \mathrm{~h}$, reflux, quant; (d) $\mathrm{NaN}_{3}, \mathrm{CH}_{3} \mathrm{CN}$, reflux, $16 \mathrm{~h}$, quant.

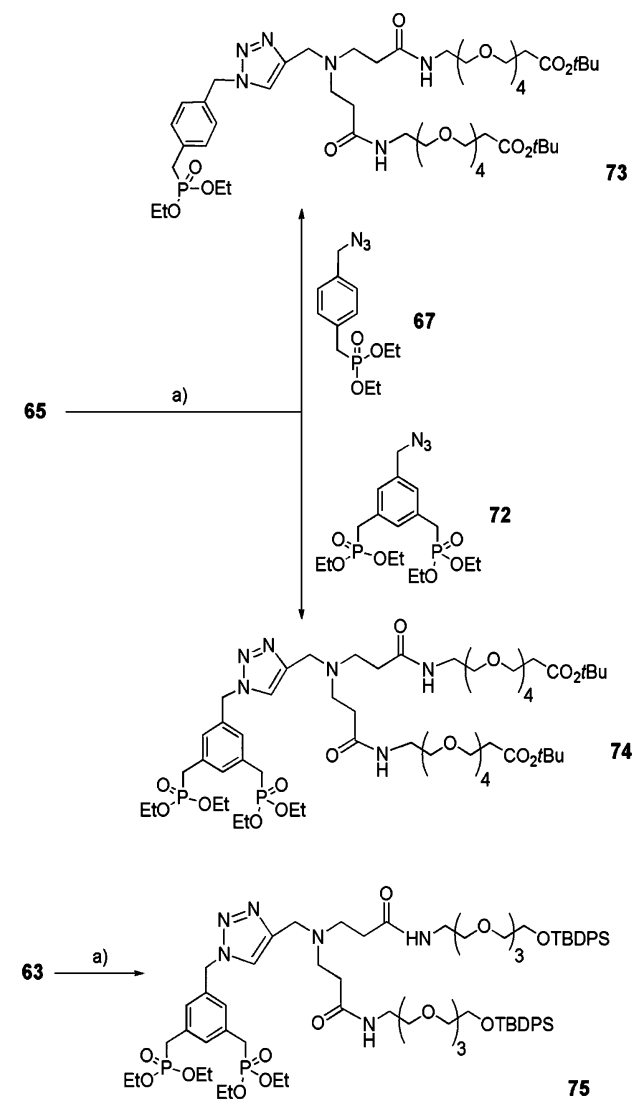

Scheme 13 Coupling between PAMAM monomers $\mathbf{6 3}$ or $\mathbf{6 5}$ and mono or bisphosphonate precursors 67 and 72 via click reaction. (a) $\mathrm{CuSO}_{4} \cdot 5 \mathrm{H}_{2} \mathrm{O}$ / sodium ascorbate, $\mathrm{THF} / \mathrm{H}_{2} \mathrm{O}(4: 1), \mathrm{rt}, 16 \mathrm{~h}(\mathbf{7 3}: 60 \%, 74: 75 \%, 75: 62 \%)$.

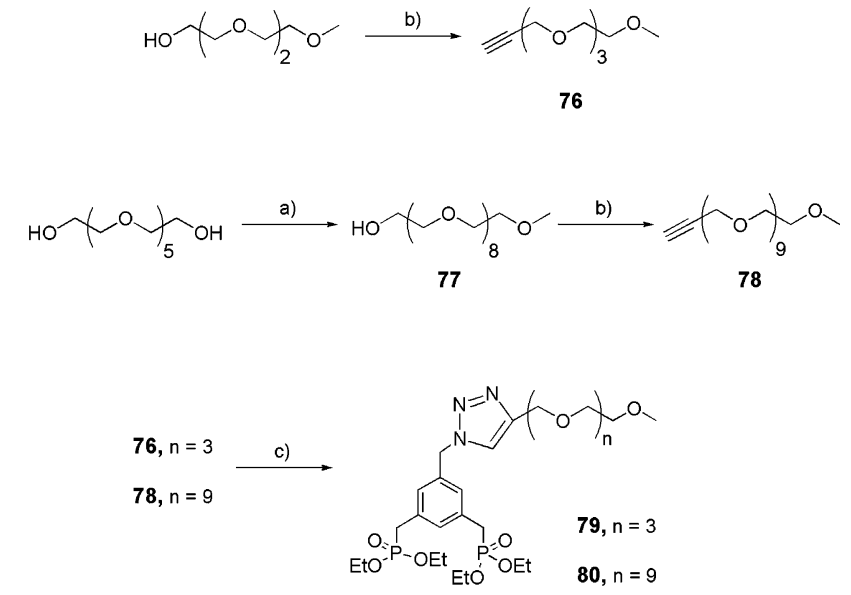

Scheme 14 Synthesis of linear bis-ethylphosphonates 79 and $\mathbf{8 0}$. (a) $\mathrm{TsO}-\mathrm{PEG}_{3}-\mathrm{Me}^{25} \mathrm{KOH}$, THF, reflux, $18 \mathrm{~h}, 65 \%$; (b) propargylbromide, tBuOK, THF, rt, 1 week; (c) 72, $\mathrm{CuSO}_{4} \cdot 5 \mathrm{H} 2 \mathrm{O} /$ sodium ascorbate, $\mathrm{THF} / \mathrm{H}_{2} \mathrm{O}$ $(4: 1), r t, 16$ h $(79: 65 \%, 80: 61 \%)$.

Functionalized and linear bis-ethyl phosphonates $\mathbf{8 6}$ and $\mathbf{8 7}$ were similarly (via click reaction) prepared starting from the azide-OEG arm 84 and 85 and the alkyne-derivatized aromatic bis-ethyl phosphonate 81 (Scheme 15).

Activated alcohols 82 and $83^{34}$ were quantitatively transformed into their azide derivatives $\mathbf{8 4}$ and $\mathbf{8 5}$ respectively via a nucleophilic substitution in the presence of sodium azide $\left(\mathrm{NaN}_{3}\right)$ in acetone, under reflux. In parallel, phenol 21 reacted with propargylbromide under basic conditions to obtain

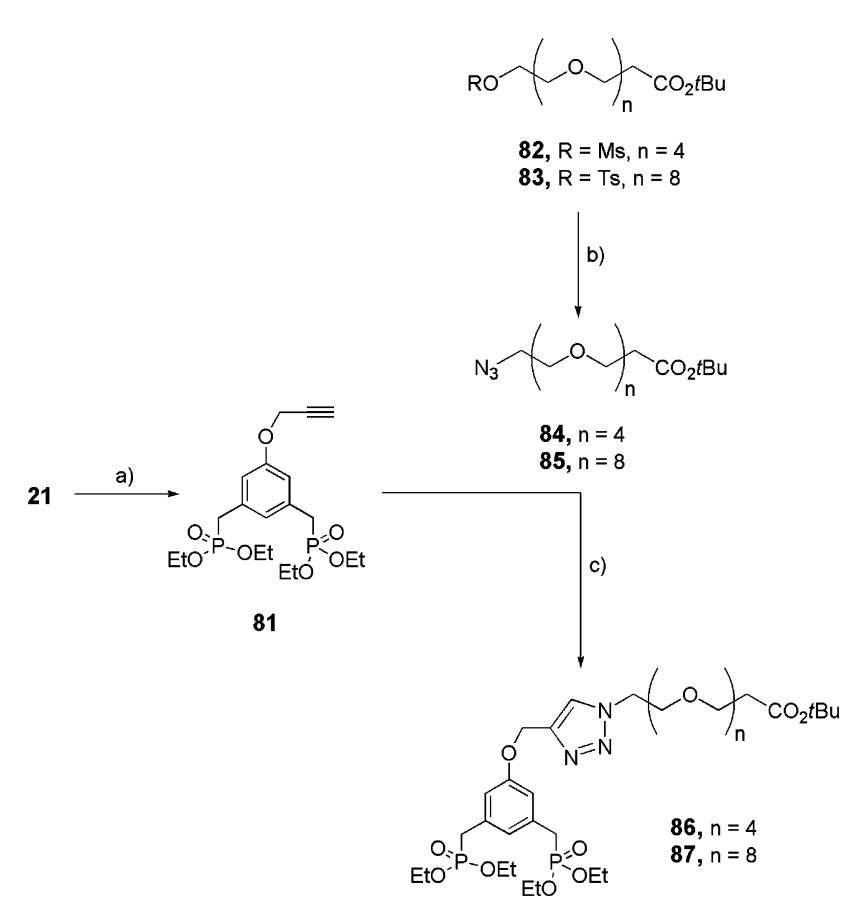

Scheme 15 Synthesis of functional bis-ethylphosphonates $\mathbf{8 6}$ and $\mathbf{8 7}$. (a) Propargylbromide, $\mathrm{K}_{2} \mathrm{CO}_{3}, 18$-crown-6, acetone, reflux, $16 \mathrm{~h}, 84 \%$; (b) $\mathrm{NaN}_{3}$, acetone, reflux, $16 \mathrm{~h}$ (84 see ref. 30, 85: quant); (c) 72, $\mathrm{CuSO}_{4}$. $5 \mathrm{H}_{2} \mathrm{O}$ /sodium ascorbate, $\mathrm{THF} / \mathrm{H}_{2} \mathrm{O}(4: 1), \mathrm{rt}, 16 \mathrm{~h}(\mathbf{8 6}: 32 \%, 87: 69 \%)$. 


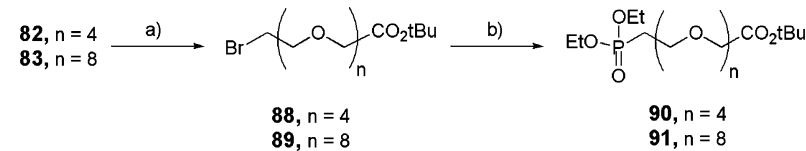

Scheme 16 Synthesis of linear and functional mono-ethylphosphonates 90 and 91. (a) $\mathrm{LiBr}$, acetone, reflux, $16 \mathrm{~h}$ (88: 72\%, 89: 70\%); (b) $\mathrm{P}(\mathrm{OEt})_{3}$, reflux, 2 h (90: quant, 91: 92\%).

alkyne-derivatized bisphosphonate $\mathbf{8 1}$ which underwent the $\mathrm{Cu}$ (II) catalyzed Huisgen 1,3-dipolar cycloaddition in the presence of 84 or 85 and sodium ascorbate as the reducing agent, to obtain 86 (34\%) and 87 (71\%), respectively, in moderate yields.

Aliphatic and hydrophilic monophosphonates were prepared in a two-step sequence starting from the activated alcohols 82 and 83 (Scheme 16). Once transformed into their corresponding halides $\mathbf{8 8}$ and $\mathbf{8 9}$, respectively, they underwent the second step of the Michaelis-Arbuzov reaction in the presence of $\mathrm{P}(\mathrm{OEt})_{3}$ to obtain ethylphosphonates 90 and 91 quantitatively.

The final deprotection of the previously mentioned mono- or bis-ethylphosphonates (Schemes 13-16) was achieved in the presence of TMSBr, which allowed the simultaneous deprotection of tert-butyl esters of compounds 73, 74, 86, 87, 90 and 91, whereas a two-step sequence was necessary to yield hydroxyfunctionalized bis-phosphonic acid 92 (Scheme 17).

Proof of concept of dendronized iron oxide nanoparticles. Designing and synthesizing hybrid materials is of utmost importance since such materials can display strong versatility and adaptability in biomedical applications due to an appropriate organic coating. Aqueous suspensions of dendronized iron oxide nanoparticles (NPs), synthesized by co-precipitation (leading to naked NPs in water) or by thermal decomposition (NPs in situ coated by oleic acid in an organic solvent), have been obtained after functionalization of NPs with either phosphonic acid 1, 2, 3, $,^{21 a, c, 22 b, 25,26 a} 4,58,60,{ }^{26 b} 92,{ }^{22 c} 93^{21 c}$ or $94^{22 c}$ (Fig. 2). Different grafting strategies have been optimized depending on the NPs synthetic method. ${ }^{21 a, 24 a, b}$ The size distribution, the colloidal stability in isoosmolar media (Fig. 3), the surface complex nature as well as the preliminary biokinetic studies performed with optical imaging, and the contrast enhancement properties evaluated through in vitro and in vivo MRI experiments, have been compared as a function of the nature of both organic shell and NPs. ${ }^{22 a-c, 25,26 a, b}$ All functionalized NPs displayed good colloidal stability in water; however, the ones bearing a peripheral carboxylic acid function gave the best results in iso-osmolar media. ${ }^{22}$

Whereas the grafting rates were similar, the nature of the surface complex depended on the NPs synthetic method. The in vitro contrast enhancement properties were better than commercial products (Table 1), with a better performance of the NPs synthesized by co-precipitation. ${ }^{25}$ On the other hand, the NPs synthesized by thermal decomposition were more efficient in vivo. However, all of our previously reported studies ${ }^{21,22,24-26}$ clearly highlighted that the dendritic organic coating impacts the nanoobject aggregation state, thus influencing the bioelimination speed and importance of the hepato-biliary versus urinary
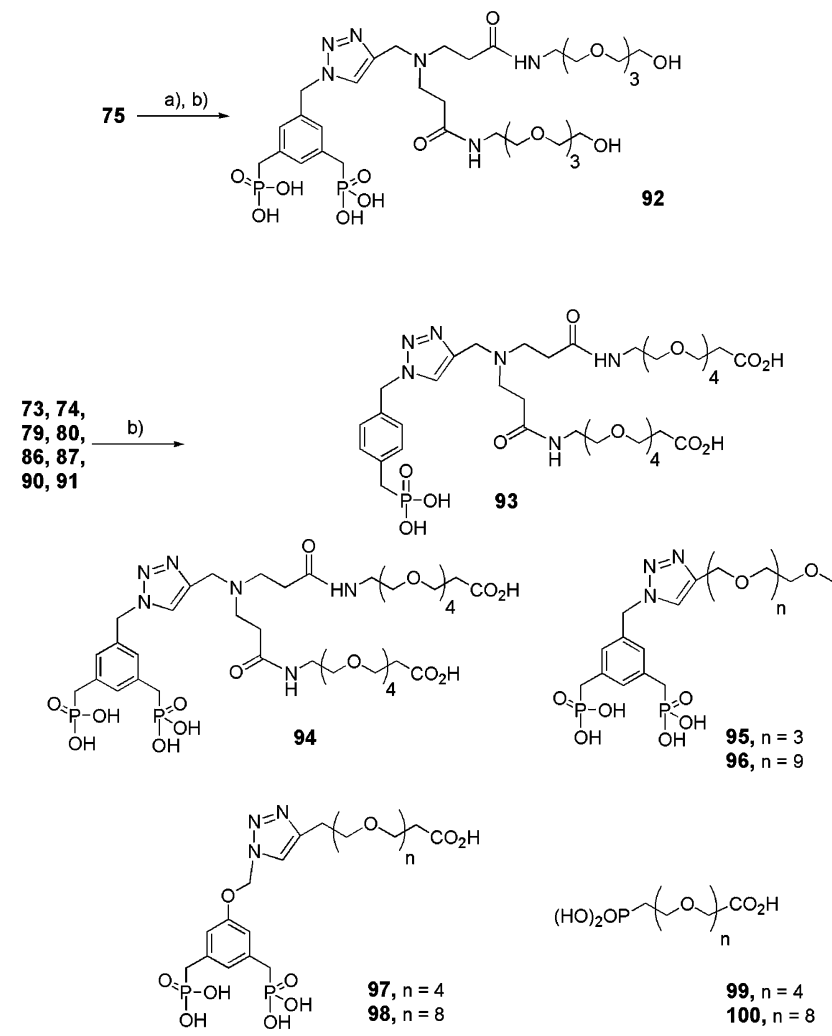

Scheme 17 Final deprotection step of functional dendritic and linear mono- and bis-ethyl phosphonates. (a) TBAF, THF, rt, $16 \mathrm{~h}$; (b) TMSBr, $\mathrm{CH}_{2} \mathrm{Cl}_{2}, \mathrm{rt}, 2-4 \mathrm{~h}(92: 75 \%, 93$ : 98\%, 94: 91\%, 95: 98\%, 96: 99\%, 97: 98\%, 98: $97 \%, 99$ : $83 \%, 100: 99 \%)$.

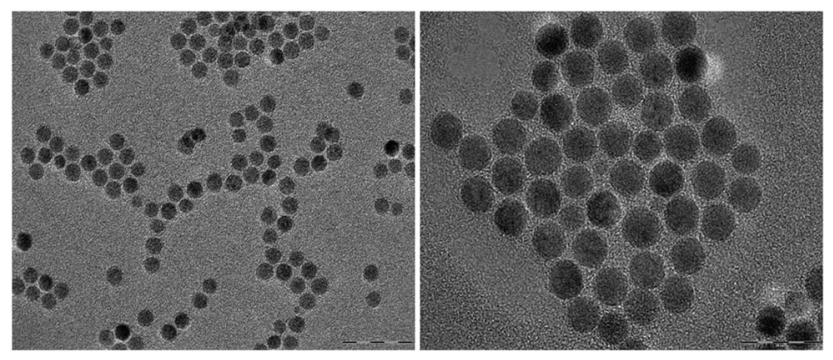

Fig. 2 TEM images of dendronized iron oxides NPs@9 94 of $10 \mathrm{~nm} .^{22 c}$

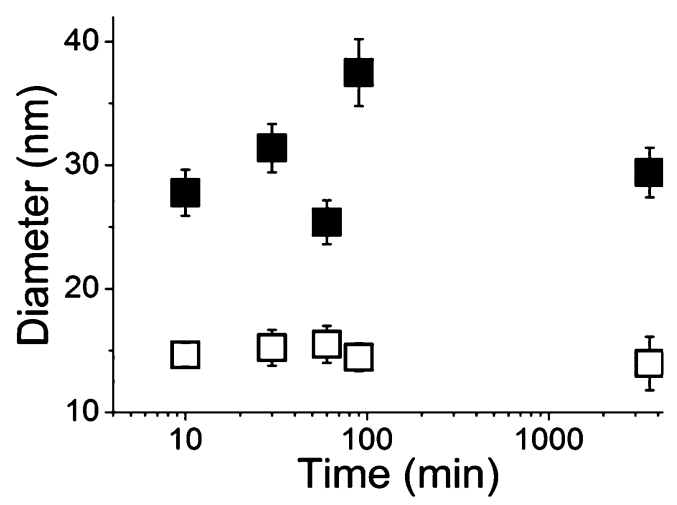

Fig. 3 Evolution of the size distribution of NP@94 ( $\square$ ) and NP@94 diluted $(\square)$ in sodium chloride medium $(0.15 \mathrm{M} \mathrm{NaCl})$ after 24 h. ${ }^{22 c}$ 
Table 1 In vitro relaxivity studies (1.5 T, room temperature) of dendronized nanoparticles compared to commercially available polymer-coated nanoparticles

\begin{tabular}{|c|c|c|c|c|c|}
\hline Compound (company) & Coating agent & $D_{\mathrm{H}}(\mathrm{nm})$ & $r 1\left(\mathrm{mM}^{-1} \mathrm{~s}^{-1}\right)$ & $r 2\left(\mathrm{mM}^{-1} \mathrm{~s}^{-1}\right)$ & $r 2 / r 1$ \\
\hline Sinerem (Guerbet) & Dextran & $51-30$ & 9.9 & 65 & 6.7 \\
\hline NP@1 & Dendritic-OEG monophosphonate & $30 \pm 1.5$ & 6.2 & 91.2 & 14.7 \\
\hline NP@94 & Dendritic-PAMAM bisphosphonate & $30 \pm 1.5$ & 7.7 & 53.8 & 7.0 \\
\hline
\end{tabular}

elimination pathway: NPs covered with small dendrons are more rapidly and completely eliminated within 24 hours post intravenous injection, predominantly by urinary elimination.

\section{Conclusions}

The chemistry of phosphonates and related multifunctional hybrids has witnessed an exponential growth, due to the potential applications of these compounds in medicine and nanobiomaterial research. A variety of discretely sized hydrophilic dendritic or linear phosphonic acids useful for the functionalization of metal oxide nanoparticles have been synthesized with high yields. A number of them were successfully grafted onto iron or manganese oxide nanoparticles through a ligand exchange method to afford stable and biocompatible nano-colloids, the bioelimination of which was mainly renal. This library of phosphonates may stimulate the development of advanced hybrid materials for better in vivo performance and sensitivity.

\section{Experimental}

\section{General}

All reactions were performed under an argon atmosphere. All the solvents, dichloromethane $\left(\mathrm{CH}_{2} \mathrm{Cl}_{2}\right)$, tetrahydrofurane (THF), acetonitrile $\left(\mathrm{CH}_{3} \mathrm{CN}\right)$, toluene, acetone, ethanol (EtOH), methanol $(\mathrm{MeOH})$, chloroform $\left(\mathrm{CHCl}_{3}\right)$, dimethylformamide (DMF), ethyl acetate (EtOAc), and cyclohexane $(\mathrm{CH})$, were of HPLC grade (chromasolv ${ }^{\mathbb{R}}$, Sigma-Aldrich) further purified in a solvent system containing drying columns or dried over $4 \AA$ molecular sieves. All commercially available reagents were used without further purification. Flash column chromatography was performed on silica gel (high-purity grade, 230-400 mesh, 40-63 $\mu \mathrm{m}$, Sigma-Aldrich) according to a standard technique. Nuclear magnetic resonance spectra $\left({ }^{1} \mathrm{H},{ }^{13} \mathrm{C}\right.$ and $\left.{ }^{31} \mathrm{P}\right)$ were recorded on a Bruker spectrometer $(300 \mathrm{MHz})$. Chemical shifts for ${ }^{1} \mathrm{H}$ and ${ }^{13} \mathrm{C}$ spectra are recorded in parts per million and are calibrated to solvent residual peaks (for example: $\mathrm{CHCl}_{3}:{ }^{1} \mathrm{H}$ 7.26 ppm, ${ }^{13} \mathrm{C} 77.16$ ppm; MeOH: $\left.{ }^{1} \mathrm{H} 3.31 \mathrm{ppm},{ }^{13} \mathrm{C} 49.00 \mathrm{ppm}\right)$ according to ref. 35. Multiplicities are indicated by s (singlet), bs (broad singlet), d (doublet), t (triplet), q (quadruplet), quint (quintuplet) and $\mathrm{m}$ (multiplet). Coupling constants, $J$, are reported in Hertz. Exact mass was obtained through Matrix Assisted Laser Desorption Ionization Time Of Flight mass spectrometry (MALDI-TOF MS).

The experimental section is composed of the syntheses of phosphonated anchors and final compounds. All the other syntheses are described in the ESI $\dagger\left({ }^{1} \mathrm{H},{ }^{13} \mathrm{C},{ }^{31} \mathrm{P}\right.$, Maldi-TOF, see ESI $\dagger$ ).

\section{Part I: amino or hydroxy-bearing mono- or bi-phosphonates}

Compound 12. Palladium activated on carbon $10 \%(0.4 \mathrm{~g}$, $0.75 \mathrm{mmol})$ was added to a solution of $\mathbf{1 1}(2.0 \mathrm{~g}, 2.6 \mathrm{mmol})$ dissolved in ethanol $(30 \mathrm{~mL})$. The mixture was stirred under a hydrogen atmosphere at room temperature for $16 \mathrm{~h}$. The product was filtered through a plug of Celite before being concentrated and purified by column chromatography $\left(\mathrm{SiO}_{2}\right.$, $\left.\mathrm{CH}_{2} \mathrm{Cl}_{2} / \mathrm{MeOH} 95: 5\right)$ to afford 12 (2.5 mmol, 96\%). Pale yellow oil. Spectroscopic data of $\mathbf{1 2}$ have already been reported in the literature. ${ }^{29}$

Compound 15. (2-Bromo-ethyl) carbamic acid tert-butyl ester (1.4 g, $6.3 \mathrm{mmol}, 3$ equiv.), $\mathrm{K}_{2} \mathrm{CO}_{3}(0.87 \mathrm{~g}, 6.3 \mathrm{mmol}, 3$ equiv.) and $\mathrm{KI}(0.05 \mathrm{~g}, 0.4 \mathrm{mmol}, 0.2$ equiv.) were added to a solution of $14(0.5 \mathrm{~g}, 2.1 \mathrm{mmol})$ in acetone $(25 \mathrm{~mL})$. The mixture was stirred for $72 \mathrm{~h}$ at $65{ }^{\circ} \mathrm{C}$, filtered over Celite and concentrated under reduced pressure. The resulting crude product was diluted in $\mathrm{CH}_{2} \mathrm{Cl}_{2}(50 \mathrm{~mL})$ and washed twice with an aqueous saturated solution of $\mathrm{NaHCO}_{3}$ and with brine. After drying over $\mathrm{MgSO}_{4}$, filtration and evaporation of the solvent, the crude product was purified by column chromatography $\left(\mathrm{SiO}_{2}, \mathrm{CH}_{2} \mathrm{Cl}_{2} / \mathrm{MeOH} 95 / 5\right)$ to afford the protected amine as yellow oil in $63 \%$ yield. Trifluoroacetic acid (1.1 mL, $13 \mathrm{mmol}, 10.0$ equiv.) was added dropwise at $0{ }^{\circ} \mathrm{C}$ to a solution of Boc-protected amine $(0.5 \mathrm{~g}$, $1.3 \mathrm{mmol})$ in $\mathrm{CH}_{2} \mathrm{Cl}_{2}(15 \mathrm{~mL})$. The reaction mixture was stirred overnight at room temperature, and then the volatiles were evaporated. The crude product was dissolved in a mixture of $\mathrm{CH}_{2} \mathrm{Cl}_{2} / \mathrm{MeOH}(9 / 1)(20 \mathrm{~mL})$ and was washed with $\mathrm{NaOH} 1 \mathrm{~N}$ $(2 \times 10 \mathrm{~mL})$. The organic layer was dried over $\mathrm{MgSO}_{4}$, filtered and concentrated under reduced pressure to afford $15(1.97 \mathrm{mmol}$, $94 \%$ ), which was used without further purification. White foam. ${ }^{1} \mathrm{H}$ NMR $\left(300 \mathrm{MHz}, \mathrm{CD}_{3} \mathrm{OD}\right) \delta 7.20(\mathrm{dd}, J=2.7$ and $8.0 \mathrm{~Hz}, 2 \mathrm{H}$, Ar-2,6- $H), 6.85(\mathrm{~d}, J=8.0 \mathrm{~Hz} 2 \mathrm{H}, \mathrm{Ar}-3,5-H), 4.02(\mathrm{~m}, 6 \mathrm{H}$, $\mathrm{OCH}_{2} \mathrm{CH}_{2} \mathrm{NH}$ and $\left.\mathrm{PO}\left(\mathrm{OCH}_{2} \mathrm{CH}_{3}\right)_{2}\right), 3.08\left(\mathrm{~m}, 4 \mathrm{H}, \mathrm{OCH}_{2} \mathrm{CH}_{2} \mathrm{NH}\right.$ and $\left.\mathrm{Ar}^{1} \mathrm{CH}_{2} \mathrm{P}\right), 1.21\left(\mathrm{t}, J=7.0 \mathrm{~Hz}, 6 \mathrm{H}, \mathrm{PO}\left(\mathrm{OCH}_{2} \mathrm{CH}_{3}\right)_{2}\right) ;{ }^{13} \mathrm{C} \mathrm{NMR}$ $\left(75 \mathrm{MHz}, \mathrm{CD}_{3} \mathrm{OD}\right) \delta 157.8(J=3.3 \mathrm{~Hz})(\mathrm{Ar}), 130.7(J=6.6 \mathrm{~Hz})(\mathrm{Ar})$, $123.6(J=9.3 \mathrm{~Hz})(\mathrm{Ar}), 114.6(J=2.7 \mathrm{~Hz})(\mathrm{Ar}), 70.0\left(\mathrm{OCH}_{2}\right), 62.0$ $(J=6.6 \mathrm{~Hz})\left(\mathrm{CH}_{2} \mathrm{CH}_{3}\right), 41.4\left(\mathrm{CH}_{2} \mathrm{NH}_{2}\right), 32.5(J=138.9 \mathrm{~Hz})(C \mathrm{H}-\mathrm{P})$, $16.3(J=6.1 \mathrm{~Hz})\left(\mathrm{CH}_{2} \mathrm{CH}_{3}\right) ;{ }^{31} \mathrm{P} \mathrm{NMR}\left(81 \mathrm{MHz}, \mathrm{CD}_{3} \mathrm{OD}\right) \delta 26.81$. MS (MALDI-TOF) $\mathrm{m} / \mathrm{z}$ calculated for $\mathrm{C}_{13} \mathrm{H}_{23} \mathrm{NO}_{4} \mathrm{P}:$ 288.13, obtained: 288.19 .

Compound 18. (2-Bromo-ethyl)carbamic acid tert-butyl ester (3.1 g, 13.9 mmol, 2.4 equiv.), $\mathrm{K}_{2} \mathrm{CO}_{3}(4.8 \mathrm{~g}, 34.6 \mathrm{mmol}, 6$ equiv.) and $\mathrm{KI}(0.2 \mathrm{~g}, 1.1 \mathrm{mmol}, 0.2$ equiv.) were added to a solution of $17(1.5 \mathrm{~g}, 5.8 \mathrm{mmol})$ in acetone $(120 \mathrm{~mL})$. The mixture was stirred for $72 \mathrm{~h}$ at $65{ }^{\circ} \mathrm{C}$, filtered over Celite and evaporated 
under reduced pressure. The resulting crude product was diluted in $\mathrm{CH}_{2} \mathrm{Cl}_{2}(100 \mathrm{~mL})$ and washed twice with an aqueous saturated solution of $\mathrm{NaHCO}_{3}$ and with brine. After drying over $\mathrm{MgSO}_{4}$, filtration and evaporation of the solvent, the crude product was purified by chromatography $\left(\mathrm{SiO}_{2}, \mathrm{CH}_{2} \mathrm{Cl}_{2} / \mathrm{MeOH}\right.$ 100 to $98 / 2$ ) to afford the protected diamine as yellow oil in $65 \%$ yield. $2.4 \mathrm{~mL}$ of trifluoroacetic acid (27.4 mmol, 20.0 equiv.) was then added dropwise to a solution of protected diamine $(0.75 \mathrm{~g}$, $1.4 \mathrm{mmol})$ in $\mathrm{CH}_{2} \mathrm{Cl}_{2}(35 \mathrm{~mL})$ at $0{ }^{\circ} \mathrm{C}$. The reaction mixture was stirred overnight at room temperature, and then the volatiles were evaporated. Compound 18 was obtained as a salt (1.3 mmol, 95\%) and was used without further purification. White foam. ${ }^{1} \mathrm{H}$ NMR (300 MHz, $\left.\mathrm{CD}_{3} \mathrm{OD}\right) \delta 6.55(\mathrm{t}, J=2.3 \mathrm{~Hz}$, $2 \mathrm{H}, \operatorname{Ar}-2,4-H), 6.42(\mathrm{~m}, 1 \mathrm{H}, \operatorname{Ar}-6-H), 4.11(\mathrm{t}, J=5.0 \mathrm{~Hz}, 4 \mathrm{H}$, $\left.\mathrm{OCH}_{2} \mathrm{CH}_{2} \mathrm{NH}\right), 3.98-3.87\left(\mathrm{~m}, 4 \mathrm{H}, \mathrm{PO}\left(\mathrm{OCH}_{2} \mathrm{CH}_{3}\right)_{2}\right), 3.23-3.20$ $\left(\mathrm{m}, 4 \mathrm{H}, \mathrm{OCH}_{2} \mathrm{CH}_{2} \mathrm{NH}_{2}\right.$ ), 3.11 (d, $J=21.8 \mathrm{~Hz}, 2 \mathrm{H}, \operatorname{ArCH}_{2} \mathrm{P}$ ), $1.18\left(\mathrm{t}, J=7.0 \mathrm{~Hz}, 6 \mathrm{H}, \mathrm{PO}\left(\mathrm{OCH}_{2} \mathrm{CH}_{3}\right)_{2}\right) ;{ }^{13} \mathrm{C} \mathrm{NMR}(75 \mathrm{MHz}$, $\left.\mathrm{CD}_{3} \mathrm{OD}\right) \delta 158.8(J=2.6 \mathrm{~Hz})(\mathrm{Ar}), 133.5(J=8.8 \mathrm{~Hz})(\mathrm{Ar}), 108.7$ $(J=6.6 \mathrm{~Hz})(\mathrm{Ar}), 99.6(J=3.3 \mathrm{~Hz})(\mathrm{Ar}), 63.5\left(\mathrm{OCH}_{2}\right), 61.9(J=7.1 \mathrm{~Hz})$ $\left(\mathrm{CH}_{2} \mathrm{CH}_{3}\right), 38.2\left(\mathrm{CH}_{2} \mathrm{NH}_{2}\right), 31.8(\mathrm{~J}=137.8 \mathrm{~Hz})(\mathrm{CH}-\mathrm{P}), 14.8(\mathrm{~J}=6.0$ $\mathrm{Hz})\left(\mathrm{CH}_{2} \mathrm{CH}_{3}\right)$; ${ }^{31} \mathrm{P}$ NMR (81 MHz, $\left.\mathrm{CD}_{3} \mathrm{OD}\right) \delta$ 27.24. MS (MALDITOF) $m / z$ calculated for $\mathrm{C}_{15} \mathrm{H}_{27} \mathrm{NaN}_{2} \mathrm{O}_{13} \mathrm{P}: 369.17$, obtained: 369.12; calculated for $\mathrm{C}_{15} \mathrm{H}_{27} \mathrm{Na}_{2} \mathrm{~N}_{2} \mathrm{O}_{13} \mathrm{P}: 392.17$, obtained: 392.15 .

Compound 22. (2-Bromo-ethyl)carbamic acid tert-butyl ester ( $1.1 \mathrm{~g}, 4.95 \mathrm{mmol}, 1.3$ equiv.), $\mathrm{K}_{2} \mathrm{CO}_{3}$ (2.1 g, $15.2 \mathrm{mmol}, 4$ equiv.) and $\mathrm{KI}(0.1 \mathrm{~g}, 0.4 \mathrm{mmol}, 0.1$ equiv. $)$ were added to a solution of $21(1.5 \mathrm{~g}, 3.8 \mathrm{mmol})$ in acetone $(40 \mathrm{~mL})$. The mixture was stirred for $48 \mathrm{~h}$ at $65{ }^{\circ} \mathrm{C}$, filtered over Celite and evaporated under reduced pressure. The resulting crude product was diluted in $\mathrm{CH}_{2} \mathrm{Cl}_{2}(100 \mathrm{~mL})$ and washed twice with an aqueous saturated solution of $\mathrm{NaHCO}_{3}$ and with brine. After drying over $\mathrm{MgSO}_{4}$, filtration and evaporation of the solvent, the crude product was purified by column chromatography $\left(\mathrm{SiO}_{2}, \mathrm{CH}_{2} \mathrm{Cl}_{2} / \mathrm{MeOH} 98 / 2\right.$ to $95 / 5)$ to afford the (Boc-amino) derivative as a white solid (76\%). The compound (1.2 g, $2.2 \mathrm{mmol})$ was then dissolved in anhydrous $\mathrm{CH}_{2} \mathrm{Cl}_{2}(30 \mathrm{~mL})$ at $0{ }^{\circ} \mathrm{C}$ and trifluoroacetic acid (2 mL, 22.0 mmol, 10.0 equiv.) was added dropwise. The reaction mixture was stirred overnight at room temperature, and then the volatiles were evaporated. The crude product was dissolved in $\mathrm{CH}_{2} \mathrm{Cl}_{2}(20 \mathrm{~mL})$ and was washed with $\mathrm{NaOH} 1 \mathrm{~N}$ $(2 \times 10 \mathrm{~mL})$. The organic layer was dried over $\mathrm{MgSO}_{4}$, filtered and concentrated under reduced pressure to afford $21(1.9 \mathrm{mmol}$, $88 \%$ ) as a white foam, which was used without further purification. ${ }^{1} \mathrm{H}$ NMR (300 MHz, $\left.\mathrm{CDCl}_{3}\right) \delta 6.72(\mathrm{~m}, 3 \mathrm{H}, \mathrm{Ar}-2,4,6-H), 5.25$ (br s, $\left.2 \mathrm{H}, \mathrm{OCH}_{2} \mathrm{CH}_{2} \mathrm{NH}_{2}\right), 4.03-3.92\left(\mathrm{~m}, 10 \mathrm{H}, \mathrm{PO}\left(\mathrm{OCH}_{2} \mathrm{CH}_{3}\right)_{2}\right.$ and $\mathrm{OCH}_{2} \mathrm{CH}_{2} \mathrm{NH}$ ), 3.10 (d, $\left.J=21.7 \mathrm{~Hz}, 4 \mathrm{H}, \mathrm{ArCH}_{2} \mathrm{P}\right), 3.02(\mathrm{~m}, 2 \mathrm{H}$, $\left.\mathrm{OCH}_{2} \mathrm{CH}_{2} \mathrm{NH}\right), 1.25$ (t, $\left.J=7.1 \mathrm{~Hz}, 12 \mathrm{H}, \mathrm{PO}\left(\mathrm{OCH}_{2} \mathrm{CH}_{3}\right)_{2}\right) ;{ }^{13} \mathrm{C} \mathrm{NMR}$ $\left(75 \mathrm{MHz}, \mathrm{CDCl}_{3}\right) \delta 159.0(J=2.8 \mathrm{~Hz})(\mathrm{Ar}), 133.1(J=6.0 \mathrm{~Hz})(\mathrm{Ar})$, $123.8(J=6.8 \mathrm{~Hz})(\mathrm{Ar}), 114.5(J=5.0 \mathrm{~Hz})(\mathrm{Ar}), 70.0\left(\mathrm{OCH}_{2}\right), 62.1$ $(J=7.0 \mathrm{~Hz})\left(\mathrm{CH}_{2} \mathrm{CH}_{3}\right), 41.5\left(\mathrm{CH}_{2} \mathrm{NH}_{2}\right), 33.5(J=138.2 \mathrm{~Hz})(C \mathrm{H}-\mathrm{P})$, $16.5(J=2.7 \mathrm{~Hz})\left(\mathrm{CH}_{2} \mathrm{CH}_{3}\right) ;{ }^{31} \mathrm{P}$ NMR $\left(81 \mathrm{MHz}, \mathrm{CDCl}_{3}\right) \delta 26.24$. MS (MALDI-TOF) $m / z$ calculated for $\mathrm{C}_{18} \mathrm{H}_{34} \mathrm{NO}_{7} \mathrm{P}_{2}$ : 438.17, obtained: 438.18; calculated for $\mathrm{C}_{18} \mathrm{H}_{34} \mathrm{NaO}_{7} \mathrm{P}_{2}$ : 460.17, obtained: 460.16 .

Compound 26. Trifluoroacetic acid $(780 \mu \mathrm{L}, 8.0 \mathrm{mmol})$ was added dropwise to a solution of $25(0.4 \mathrm{~g}, 0.4 \mathrm{mmol})$ in $\mathrm{CH}_{2} \mathrm{Cl}^{2}$ $(15 \mathrm{~mL})$ at $0{ }^{\circ} \mathrm{C}$. The reaction mixture was stirred overnight at room temperature, and then the volatiles were evaporated. The compound 26 was obtained as a salt (0.39 mmol, 98\%) and was used without further purification. White foam. ${ }^{1} \mathrm{H}$ NMR (300 MHz, CD3OD) $\delta 8.74\left(\mathrm{~m}, 1 \mathrm{H}, \mathrm{Ar}^{1} \mathrm{OCH}_{2} \mathrm{CH}_{2} \mathrm{NH}\right), 8.55$ (m, 4H, $\mathrm{Ar}^{2} \mathrm{OCH}_{2} \mathrm{CH}_{2} \mathrm{NH}_{2}$ ), $6.95\left(\mathrm{~m}, 2 \mathrm{H}, \mathrm{Ar}^{1}-2,6-\mathrm{H}\right), 6.85-6.78$ $\left(\mathrm{m}, 3 \mathrm{H}, \mathrm{Ar}^{2}-2,4,6-H\right), 6.69\left(\mathrm{~m}, 1 \mathrm{H}, \mathrm{Ar}^{1}-4-H\right), 4.21(\mathrm{~m}, 2 \mathrm{H}$, $\left.\mathrm{Ar}^{1} \mathrm{OCH}_{2} \mathrm{CH}_{2} \mathrm{NH}\right), 4.05-3.90\left(\mathrm{~m}, 12 \mathrm{H}, \mathrm{Ar}^{2} \mathrm{OCH}_{2} \mathrm{CH}_{2} \mathrm{NH}\right.$ and $\left.\mathrm{PO}\left(\mathrm{OCH}_{2} \mathrm{CH}_{3}\right)_{2}\right), 3.78\left(\mathrm{~m}, 2 \mathrm{H}, \quad \mathrm{Ar}^{1} \mathrm{OCH}_{2} \mathrm{CH}_{2} \mathrm{NH}\right), 3.58-3.50$ (m, $4 \mathrm{H}, \mathrm{Ar}^{2} \mathrm{OCH}_{2} \mathrm{CH}_{2} \mathrm{NH}$ ), 3.08 (d, $J=22.0 \mathrm{~Hz}, 4 \mathrm{H}, \mathrm{Ar}^{1} \mathrm{CH}_{2} \mathrm{P}$ ), $1.25\left(\mathrm{t}, J=7.0 \mathrm{~Hz}, 12 \mathrm{H}, \mathrm{PO}\left(\mathrm{OCH}_{2} \mathrm{CH}_{3}\right)_{2}\right) ;{ }^{13} \mathrm{C} \mathrm{NMR}(75 \mathrm{MHz}$, CD3OD) $\delta 167.8(\mathrm{CONH}), 158.7$ (Ar), 136.2 (Ar), $132.5(\mathrm{Ar}), 123.3$ (Ar), $114.1(J=4.9 \mathrm{~Hz})(\mathrm{Ar}), 105.8(\mathrm{Ar}), 104.4(\mathrm{Ar}), 65.6\left(\mathrm{OCH}_{2}-\right.$ $\left.\mathrm{CH}_{2} \mathrm{NH}\right), 63.8\left(\mathrm{OCH}_{2} \mathrm{CH}_{2} \mathrm{NH}_{2}\right), 61.9(\mathrm{~J}=3.3 \mathrm{~Hz})\left(\mathrm{CH}_{2} \mathrm{CH}_{3}\right), 38.8$ ( $\left.\mathrm{CH}_{2} \mathrm{NHCOAr}\right), 38.2\left(\mathrm{CH}_{2} \mathrm{NH}_{2}\right), 31.4(J=147.8 \mathrm{~Hz})(\mathrm{CH}-\mathrm{P}), 14.8$ $(J=2.7 \mathrm{~Hz})\left(\mathrm{CH}_{2} \mathrm{CH}_{3}\right) ;{ }^{31} \mathrm{P} \mathrm{NMR}\left(81 \mathrm{MHz}, \mathrm{CD}_{3} \mathrm{OD}\right) \delta 27.41 . \mathrm{MS}$ (MALDI-TOF) $\mathrm{m} / \mathrm{z}$ calculated for $\mathrm{C}_{29} \mathrm{H}_{48} \mathrm{~N}_{3} \mathrm{O}_{14} \mathrm{P}_{2}: 660.27$, obtained: 660.24 ; calculated for $\mathrm{C}_{29} \mathrm{H}_{48} \mathrm{NaN}_{3} \mathrm{O}_{14} \mathrm{P}_{2}$ : 682.27, obtained: 682.22 .

\section{General procedure for the conversion of phosphonate ester to} phosphonic acid by TMSBr (McKenna's method ${ }^{28}$ ) (40-43)

TMSBr (10.0 equiv. per ethyl phosphonate and tert-butyl ester function) was added dropwise to a solution of ethyl phosphonate (36-39) in $\mathrm{CH}_{2} \mathrm{Cl}_{2}$ at $0{ }^{\circ} \mathrm{C}$. After stirring overnight at room temperature, the volatiles were evaporated and $\mathrm{MeOH}$ was added to the crude product, and then evaporated. The phosphonic acid was obtained without further purification.

Compound 40. Starting from $36(0.13 \mathrm{~g}, 0.10 \mathrm{mmol})$ and TMSBr (0.26 mL, 2 mmol, 20 equiv.), 40 was obtained (0.09 mmol, 93\%) as an orange oil. ${ }^{1} \mathrm{H}$ NMR (300 $\mathrm{MHz}, \mathrm{CD}_{3} \mathrm{OD}$ ) $\delta$ 7.307.25 (m, 4H, $\mathrm{Ar}^{1}-2,6-\mathrm{H}$ and $\left.\mathrm{Ar}^{2}-2,6-H\right), 6.97$ (d, $J=8.3 \mathrm{~Hz}$, $\left.2 \mathrm{H}, \mathrm{Ar}^{1}-3,5-\mathrm{H}\right), 4.31-4.18\left(\mathrm{~m}, 8 \mathrm{H}, \mathrm{Ar}^{1} \mathrm{OCH}_{2} \mathrm{CH}_{2} \mathrm{NH}\right.$ and $\mathrm{Ar}^{2} \mathrm{OCH}_{2}-$ $\left.\mathrm{CH}_{2} \mathrm{O}\right), 3.93\left(\mathrm{~m}, 6 \mathrm{H}, \mathrm{OCH}_{2} \mathrm{CH}_{2} \mathrm{O}\right), 3.85-3.50\left(\mathrm{~m}, 56 \mathrm{H}, \mathrm{OCH}_{2}-\right.$ $\mathrm{CH}_{2} \mathrm{O}$ ), 3.41 (s, 6H, $\mathrm{OCH}_{2} \mathrm{CH}_{2} \mathrm{OCH}_{3}$ ), 3.12 (d, $J=21.3 \mathrm{~Hz}, 2 \mathrm{H}$, $\mathrm{Ar}^{1} \mathrm{CH}_{2} \mathrm{P}$ ), $2.63\left(\mathrm{t}, 2 \mathrm{H}, J=6.1 \mathrm{~Hz}, \mathrm{Ar}^{2} \mathrm{OCH}_{2} \mathrm{CH}_{2} \mathrm{COOH}\right) ;{ }^{13} \mathrm{C} \mathrm{NMR}$ (75 MHz, $\left.\mathrm{CD}_{3} \mathrm{OD}\right) \delta 171.8(\mathrm{COOH}), 167.8(\mathrm{NHCO}), 157.2(\mathrm{Ar})$, 151.8 (Ar), 140.4 (Ar), $130.1(J=6.0 \mathrm{~Hz}$ ) (Ar), $128.5(\mathrm{Ar}), 124.3$ $(J=9.3 \mathrm{~Hz}$ ) (Ar), 113.8 (Ar), 106.1 (Ar), 71.8 (PEG), 71.0 (PEG), 69.9 (PEG), 69.8 (PEG), 69.7 (PEG), 69.6 (PEG), 69.4 (PEG), 69.3 (PEG), 68.9 (PEG), 68.2 (PEG), $65.8\left(\mathrm{OCH}_{2} \mathrm{CH}_{2} \mathrm{NH}\right), 65.6\left(\mathrm{CH}_{2} \mathrm{CH}_{2} \mathrm{COO}\right)$, $57.2\left(\mathrm{OCH}_{3}\right), 50.1,39.0\left(\mathrm{CH}_{2} \mathrm{NHCOAr}\right), 33.9\left(\mathrm{CH}_{2} \mathrm{COO}\right), 32.8$ $(J=135.5 \mathrm{~Hz})(C \mathrm{H}-\mathrm{P}) ;{ }^{31} \mathrm{P} \mathrm{NMR}\left(81 \mathrm{MHz}, \mathrm{CD}_{3} \mathrm{OD}\right) \delta 25.32 . \mathrm{MS}$ (MALDI-TOF) $m / z$ calculated for $\mathrm{C}_{53} \mathrm{H}_{90} \mathrm{NaNO}_{26} \mathrm{P}: 1210.55$ obtained: 1220.57; calculated for $\mathrm{C}_{61} \mathrm{H}_{106} \mathrm{KNO}_{26} \mathrm{P}: 1226.55$, obtained: 1226.58 .

Compound 41. Starting from $37(0.1 \mathrm{~g}, 0.04 \mathrm{mmol})$ and TMSBr (0.16 mL, 1.2 mmol, 30 equiv.), 41 was obtained (0.034 mmol, 86\%) as an orange oil. ${ }^{1} \mathrm{H}$ NMR $(300 \mathrm{MHz}$, $\left.\mathrm{CD}_{3} \mathrm{OD}\right) \delta 7.28\left(\mathrm{~s}, 4 \mathrm{H}, \mathrm{Ar}^{2}-2,6-H\right), 6.62\left(\mathrm{t}, 2 \mathrm{H}, J=2.0 \mathrm{~Hz}, \mathrm{Ar}^{1}-\right.$ 2,6-H), 6.51 (t, $\left.J=2.0 \mathrm{~Hz}, 1 \mathrm{H}, \mathrm{Ar}^{1}-4-H\right), 4.30-4.25(\mathrm{~m}, J=4.3 \mathrm{~Hz}$, $\left.12 \mathrm{H}, \mathrm{Ar}^{2} \mathrm{OCH}_{2} \mathrm{CH}_{2} \mathrm{O}\right), 4.20\left(\mathrm{t}, 4 \mathrm{H}, J=5.3 \mathrm{~Hz}, \mathrm{Ar}^{1} \mathrm{OCH}_{2} \mathrm{CH}_{2} \mathrm{NH}\right)$, 3.95-3.75 (m, $16 \mathrm{H}, \mathrm{Ar}^{1} \mathrm{OCH}_{2} \mathrm{CH}_{2} \mathrm{NH}$ and $\mathrm{OCH}_{2} \mathrm{CH}_{2} \mathrm{O}$ ), 3.80-3.55 $\left(\mathrm{m}, 108 \mathrm{H}, \mathrm{OCH}_{2} \mathrm{CH}_{2} \mathrm{O}\right), 3.41\left(\mathrm{~s}, 12 \mathrm{H}, \mathrm{OCH}_{2} \mathrm{CH}_{2} \mathrm{OCH}_{3}\right), 3.12$ $\left(\mathrm{d}, J=21.4 \mathrm{~Hz}, 2 \mathrm{H}, \mathrm{Ar}^{1} \mathrm{CH}_{2} \mathrm{P}\right), 2.62\left(\mathrm{t}, 4 \mathrm{H}, J=6.6 \mathrm{~Hz}, \mathrm{Ar}^{2} \mathrm{OCH}_{2} \mathrm{CH}_{2-}\right.$ $\mathrm{COOH}) ;{ }^{13} \mathrm{C}$ NMR (75 MHz, $\left.\mathrm{CD}_{3} \mathrm{OD}\right) \delta 172.2(\mathrm{COOH}), 168.2$ (NHCO), $159.8(J=3.3 \mathrm{~Hz})(\mathrm{Ar}), 152.2(\mathrm{Ar}), 141.1(\mathrm{Ar}), 129.2$ (Ar), $108.7(J=6.6 \mathrm{~Hz})(\mathrm{Ar}), 106.4(\mathrm{Ar}), 72.2$ (PEG), 71.6 (PEG), 
70.3 (PEG), 70.2 v, 70.1 (PEG), 70.0 (PEG), 70.3 (PEG), 69.9 (PEG), 69.5 (PEG), 68.7 (PEG), $66.3\left(\mathrm{OCH}_{2} \mathrm{CH}_{2} \mathrm{NH}\right), 66.1\left(\mathrm{CH}_{2} \mathrm{CH}_{2} \mathrm{COO}\right)$, $57.8\left(\mathrm{OCH}_{3}\right), 50.8,39.5\left(\mathrm{CH}_{2} \mathrm{NHCOAr}\right), 33.8\left(\mathrm{CH}_{2} \mathrm{COO}\right), 32.6$ $(J=133.4 \mathrm{~Hz})(\mathrm{CH}-\mathrm{P}) ;{ }^{31} \mathrm{P}$ NMR $\left(81 \mathrm{MHz}, \mathrm{CD}_{3} \mathrm{OD}\right) \delta 24.22 . \mathrm{MS}$ (MALDI-TOF) $\mathrm{m} / \mathrm{z}$ calculated for $\mathrm{C}_{99} \mathrm{H}_{171} \mathrm{NaN}_{2} \mathrm{O}_{49} \mathrm{P}: 2223.07$ obtained: 2223.09.

Compound 42. Starting from $38(0.2 \mathrm{~g}, 0.14 \mathrm{mmol})$ and TMSBr (0.55 mL, $3 \mathrm{mmol}, 30$ equiv.), 42 was obtained (0.13 mmol, 94\%) as an orange oil. ${ }^{1} \mathrm{H} \mathrm{NMR}\left(300 \mathrm{MHz}, \mathrm{CD}_{3} \mathrm{OD}\right)$ $\delta 7.28\left(\mathrm{~s}, 2 \mathrm{H}, \mathrm{Ar}^{2}-2,6-H\right)$, 6.92-6.86 (m, 3H, $\left.\mathrm{Ar}^{1}-2,4,6-H\right)$, 4.35$4.20\left(\mathrm{~m}, 8 \mathrm{H}, \mathrm{Ar}^{2} \mathrm{OCH}_{2} \mathrm{CH}_{2} \mathrm{O}\right.$ and $\left.\mathrm{Ar}^{1} \mathrm{OCH}_{2} \mathrm{CH}_{2} \mathrm{NH}\right), 3.92-3.82$ $\left(\mathrm{m}, 8 \mathrm{H}, \mathrm{Ar}^{1} \mathrm{OCH}_{2} \mathrm{CH}_{2} \mathrm{NH}\right.$ and $\left.\mathrm{OCH}_{2} \mathrm{CH}_{2} \mathrm{O}\right), 3.80-3.53(\mathrm{~m}, 54 \mathrm{H}$, $\mathrm{OCH}_{2} \mathrm{CH}_{2} \mathrm{O}$ ), 3.38 (s, $6 \mathrm{H}, \mathrm{OCH}_{2} \mathrm{CH}_{2} \mathrm{OCH}_{3}$ ), 3.18 (d, $J=21.8 \mathrm{~Hz}$, $4 \mathrm{H}, \mathrm{Ar}^{1} \mathrm{CH}_{2} \mathrm{P}$ ), $2.62\left(\mathrm{t}, 2 \mathrm{H}, J=6.0 \mathrm{~Hz}, \mathrm{Ar}^{2} \mathrm{OCH}_{2} \mathrm{CH}_{2} \mathrm{COOH}\right) ;{ }^{13} \mathrm{C}$ NMR (75 MHz, $\left.\mathrm{CD}_{3} \mathrm{OD}\right) \delta 172.2(\mathrm{COOH}), 167.1$ (NHCO), 158.8 (Ar), $152.3(\mathrm{Ar}), 141.0(\mathrm{Ar}), 134.8(J=6.0 \mathrm{~Hz})(\mathrm{Ar}), 128.8(\mathrm{Ar})$, 123.8 (Ar), 114.3 (Ar), 106.4 (Ar), 72.2 (PEG), 71.7 (PEG), 70.4 (PEG), 70.25 (PEG), 70.15 (PEG), 70.1 (PEG), 70.0 (PEG), 69.95 (PEG), 69.4 (PEG), 68.8 (PEG), $66.3\left(\mathrm{OCH}_{2} \mathrm{CH}_{2} \mathrm{NH}\right), 66.1$ ( $\left.\mathrm{CH}_{2} \mathrm{CH}_{2} \mathrm{COO}\right), 57.8$ (OCH3), 50.8, $39.6\left(\mathrm{CH}_{2} \mathrm{NHCOAr}\right), 34.6$ $\left(\mathrm{CH}_{2} \mathrm{COO}\right), 33.6(\mathrm{~J}=134.5 \mathrm{~Hz})(\mathrm{CH}-\mathrm{P}) ;{ }^{31} \mathrm{P}$ NMR $(81 \mathrm{MHz}$, $\left.\mathrm{CD}_{3} \mathrm{OD}\right) \delta$ 25.19. MS (MALDI-TOF) $\mathrm{m} / \mathrm{z}$ calculated for $\mathrm{C}_{54} \mathrm{H}_{94} \mathrm{NO}_{29} \mathrm{P}_{2}$ : 1282.53, obtained: 1282.46; calculated for $\mathrm{C}_{54} \mathrm{H}_{93} \mathrm{NaNO}_{29} \mathrm{P}_{2}$ : 1304.53, obtained: 1304.45 .

Compound 43. Starting from $39(0.08 \mathrm{~g}, 0.03 \mathrm{mmol})$ and TMSBr (0.16 mL, $1.2 \mathrm{mmol}, 40$ equiv.), 43 was obtained (0.028 mmol, 93\%) as an orange oil. ${ }^{1} \mathrm{H} \mathrm{NMR}\left(300 \mathrm{MHz}, \mathrm{CD}_{3} \mathrm{OD}\right)$ $\delta 7.27$ (s, $4 \mathrm{H}, \mathrm{Ar}^{3}-2,6-H$ and $\left.\mathrm{Ar}^{2}-4-H\right), 7.11$ (d, $J=1.7 \mathrm{~Hz}, 2 \mathrm{H}, \mathrm{Ar}^{2}-2,6-$ $H$ ), 6.90-6.85 (m, 3H, $\left.\mathrm{Ar}^{1}-2,4,6-H\right), 6.82$ (m, 1H, $\left.\mathrm{Ar}^{2}-4-H\right), 4.30-4.18$ (m, $18 \mathrm{H}, \mathrm{Ar}^{1} \mathrm{OCH}_{2} \mathrm{CH}_{2} \mathrm{NH}, \mathrm{Ar}^{2} \mathrm{OCH}_{2} \mathrm{CH}_{2} \mathrm{NH}$ and $\mathrm{Ar}^{3} \mathrm{OCH}_{2} \mathrm{CH}_{2} \mathrm{O}$ ), 3.95-3.83 (m, 18H, $\mathrm{Ar}^{1} \mathrm{OCH}_{2} \mathrm{CH}_{2} \mathrm{NH}, \mathrm{Ar}^{2} \mathrm{OCH}_{2} \mathrm{CH}_{2} \mathrm{NH}$ and $\mathrm{OCH}_{2-}$ $\mathrm{CH}_{2} \mathrm{O}$ ), 3.80-3.53 (m, $\left.108 \mathrm{H}, \mathrm{OCH}_{2} \mathrm{CH}_{2} \mathrm{O}\right), 3.38\left(\mathrm{~s}, 12 \mathrm{H}, \mathrm{OCH}_{2-}\right.$ $\mathrm{CH}_{2} \mathrm{OCH}_{3}$ ), 3.12 (d, $\left.J=21.6 \mathrm{~Hz}, 4 \mathrm{H}, \operatorname{Ar}^{1} \mathrm{CH}_{2} \mathrm{P}\right), 2.63(\mathrm{t}, 4 \mathrm{H}$, $\left.J=6.6 \mathrm{~Hz}, \mathrm{Ar}^{3} \mathrm{OCH}_{2} \mathrm{CH}_{2} \mathrm{COOH}\right) ;{ }^{13} \mathrm{C} \mathrm{NMR}\left(75 \mathrm{MHz}, \mathrm{CD}_{3} \mathrm{OD}\right) \delta$ $172.1(\mathrm{COOH}), 168.2$ (NHCO), $159.9(\mathrm{Ar}), 158.8(\mathrm{Ar}), 152.2(\mathrm{Ar})$, 140.8 (Ar), 136.2 (Ar), 134.3 (Ar), 129.0 (Ar), 114.3 (Ar), 106.5 (Ar), 105.8 (Ar), 104.5 (Ar), 72.2 (PEG), 71.5 (PEG), 70.3 (PEG), 70.2 (PEG), 70.1 (PEG), 70.0 (PEG), 69.95 (PEG), 69.9 (PEG), 69.4 (PEG), 68.6 (PEG), $66.2\left(\mathrm{OCH}_{2} \mathrm{CH}_{2} \mathrm{NH}\right), 65.8\left(\mathrm{CH}_{2} \mathrm{CH}_{2} \mathrm{COO}\right), 57.8\left(\mathrm{OCH}_{3}\right)$, 50.8, $39.4\left(\mathrm{CH}_{2} \mathrm{NHCOAr}\right), 34.5\left(\mathrm{CH}_{2} \mathrm{COO}\right), 34.1(\mathrm{~J}=136.2 \mathrm{~Hz})$ $(C \mathrm{H}-\mathrm{P}) ;{ }^{31} \mathrm{P}$ NMR (81 MHz, $\left.\mathrm{CD}_{3} \mathrm{OD}\right) \delta$ 24.03. MS (MALDI-TOF) $\mathrm{m} / z$ calculated for $\mathrm{C}_{79} \mathrm{H}_{127} \mathrm{~N}_{3} \mathrm{O}_{34} \mathrm{P}_{2}$ : 1723.78, obtained: 1723.46; calculated for $\mathrm{C}_{29} \mathrm{H}_{53} \mathrm{NaO}_{14} \mathrm{P}$ : 679.31, obtained: 679.24.

General procedure for the conversion of phosphonate ester to phosphonic acid by TMSBr (McKenna's method $\left.{ }^{28}\right)(52,54,56$, 58 , and 60)

TMSBr (10.0 equiv. per ethyl phosphonate) was added dropwise to a solution of ethyl phosphonate $(51,53,55,57,59)$ in $\mathrm{CH}_{2} \mathrm{Cl}_{2}$ at $0{ }^{\circ} \mathrm{C}$. After stirring overnight at room temperature, the volatiles were evaporated and $\mathrm{MeOH}$ was added to the crude product and then evaporated several times. The phosphonic acid was obtained without further purification.

Compound 52. Starting from $51(0.12 \mathrm{~g}, 0.07 \mathrm{mmol}), 52$ was obtained (0.06 mmol, 90\%) as a dark yellow-green foam without further purification. ${ }^{1} \mathrm{H} \mathrm{NMR}\left(300 \mathrm{MHz}, \mathrm{CD}_{3} \mathrm{OD}\right) \delta 8.77(\mathrm{~s}, 1 \mathrm{H}$,
ArTriazole- $H$ ), 8.54 (d, $J=1.9 \mathrm{~Hz}, 1 \mathrm{H}$, Ardye-2- $H$ ), 8.09 (dd, $J=1.7$ and $7.9 \mathrm{~Hz}, 1 \mathrm{H}$, Ardye-6- $H$ ), $7.62(\mathrm{~d}, 4 \mathrm{H}, J=8.2 \mathrm{~Hz}$, Ardye-AA' $-H)$, $7.52(\mathrm{~d}, J=7.8 \mathrm{~Hz}, 1 \mathrm{H}$, Ardye-5- $H$ ), $7.44(\mathrm{~d}, 4 \mathrm{H}, J=9.4 \mathrm{~Hz}$, Ardye$\left.\mathrm{BB}^{\prime}-H\right), 6.68\left(\mathrm{~d}, J=2.2 \mathrm{~Hz}, 2 \mathrm{H}, \mathrm{Ar}^{1}-2,6-H\right), 5.34\left(\mathrm{~s}, 2 \mathrm{H}, \mathrm{OCH}_{2} \mathrm{Ar}-\right.$ Triazole- $\left.\mathrm{CH}_{2}\right), 4.89\left(\mathrm{t}, J=4.6 \mathrm{~Hz}, 2 \mathrm{H}, \mathrm{OCH}_{2}\right.$ ArTriazole- $\left.\mathrm{CH}_{2}\right), 4.18$ (t, $\left.J=4.4 \mathrm{~Hz}, 4 \mathrm{H}, \mathrm{Ar}^{1} \mathrm{OCH}_{2} \mathrm{CH}_{2}\right), 4.04\left(\mathrm{t}, J=4.6 \mathrm{~Hz}, 2 \mathrm{H}, \mathrm{CH}_{2}-\right.$ $\left.\mathrm{CH}_{2} \mathrm{NHO}_{2}\right), 3.88-3.80\left(\mathrm{~m}, 12 \mathrm{H}, \mathrm{OCH}_{2} \mathrm{CH}_{2} \mathrm{O}\right.$ and $\left.\mathrm{N}\left(\mathrm{CH}_{2} \mathrm{CH}_{3}\right)_{2}\right)$, 3.72-3.50 (m, 50H, $\left.\mathrm{OCH}_{2} \mathrm{CH}_{2} \mathrm{O}\right), 3.32\left(\mathrm{~s}, 6 \mathrm{H}, \mathrm{OCH}_{2} \mathrm{CH}_{2} \mathrm{OCH}_{3}\right)$, $3.18\left(\mathrm{t}, J=5.2 \mathrm{~Hz}, 2 \mathrm{H}, \mathrm{CH}_{2} \mathrm{CH}_{2} \mathrm{NHO}_{2}\right), 3.14(\mathrm{~d}, J=22.0 \mathrm{~Hz}, 2 \mathrm{H}$, $\left.\operatorname{Ar}^{1} \mathrm{CH}_{2} \mathrm{P}\right), 1.31\left(\mathrm{t}, J=7.1 \mathrm{~Hz}, 12 \mathrm{H}, \mathrm{N}\left(\mathrm{CH}_{2} \mathrm{CH}_{3}\right)_{2}\right) ; 13 \mathrm{C} \mathrm{NMR}$ $\left(75 \mathrm{MHz}, \mathrm{CD}_{3} \mathrm{OD}\right) \delta 158.5(J=3.3 \mathrm{~Hz})$ (Ardye $\left.=\mathrm{N}\right), 145.2(\mathrm{Ar})$, 142.1 (ArTriazole), 140.6 (Ar), 139.5 (Ar), 139.1 (Ar), $134.2(\mathrm{Ar})$, $131.8(\mathrm{Ar}), 129.5(\mathrm{~J}=8.8 \mathrm{~Hz})(\mathrm{Ar}), 127.6$ (ArTriazole), $127.2(\mathrm{Ar})$, $127.1(\mathrm{Ar}), 125.8(\mathrm{Ar}), 116.0(\mathrm{Ar}), 107.8(\mathrm{~J}=6.6 \mathrm{~Hz})(\mathrm{Ar}), 71.9$ (OCH2-ArTriazole), 71.0 (PEG), 70.7 (PEG), 70.6 (PEG), 70.5 (PEG), 70.4 (PEG), 68.8 (PEG), 68.6 (PEG), $67.5\left(\mathrm{OCH}_{2} \mathrm{CH}_{2} \mathrm{NH}\right)$, 62.5 (PEG), 60.2 (PEG), $57.2\left(\mathrm{OCH}_{3}\right), 52.2\left(\right.$ ArTriazole- $\left.\mathrm{CH}_{2}\right), 48.4$ $\left(\mathrm{N}\left(\mathrm{CH}_{2} \mathrm{CH}_{3}\right)_{2}\right), 42.1\left(\mathrm{CH}_{2} \mathrm{NHSO}_{2}\right), 33.9(\mathrm{~J}=138.5 \mathrm{~Hz})(\mathrm{CH}-\mathrm{P})$, $10.8\left(\mathrm{~N}\left(\mathrm{CH}_{2} \mathrm{CH}_{3}\right)_{2}\right) ;{ }^{31} \mathrm{P}$ NMR (81 MHz, $\left.\mathrm{CD}_{3} \mathrm{OD}\right) \delta$ 24.09. MS (MALDI-TOF) $\mathrm{m} / \mathrm{z}$ calculated for $\mathrm{C}_{71} \mathrm{H}_{112} \mathrm{~N}_{6} \mathrm{O}_{26} \mathrm{PS}_{2}$ : 1559.67, obtained: 1559.56; calculated for $\mathrm{C}_{71} \mathrm{H}_{111} \mathrm{NaN}_{6} \mathrm{O}_{26} \mathrm{PS}_{2}$ : 1581.67, obtained: 1581.55 .

Compound 54. Starting from $53(0.11 \mathrm{~g}, 0.06 \mathrm{mmol}), 54$ was obtained (0.055 mmol, 94\%) as a dark yellow-green foam without further purification. ${ }^{1} \mathrm{H}$ NMR $\left(300 \mathrm{MHz}, \mathrm{CD}_{3} \mathrm{OD}\right)$ $\delta 8.82(\mathrm{~s}, 1 \mathrm{H}$, ArTriazole- $H), 8.61(\mathrm{~m}, 1 \mathrm{H}$, Ardye-2- $H), 8.18$ $(\mathrm{m}, 1 \mathrm{H}$, Ardye-6- $H), 7.72-7.52(\mathrm{~m}, 9 \mathrm{H}$, Ardye-5- $H$, Ardye-AA' $-H$ and Ardye-BB' $-H$ ), 7.36 (s, 2H, Ar2-2,6-H), 7.28 (d, $2 \mathrm{H}, J=7.6 \mathrm{~Hz}$, $\left.\operatorname{Ar}^{1}-2,6-H\right), 6.97$ (d, 2H, $\left.J=7.6 \mathrm{~Hz}, \operatorname{Ar}^{1}-3,5-H\right), 5.49(\mathrm{~s}, 2 \mathrm{H}$, $\mathrm{OCH}_{2}$ ArTriazole- $\left.\mathrm{CH}_{2}\right), 4.95\left(\mathrm{~m}, 2 \mathrm{H}, \mathrm{OCH}_{2}\right.$ ArTriazole- $\left.\mathrm{CH}_{2}\right), 4.30$ $\left(\mathrm{m}, 4 \mathrm{H}, \mathrm{Ar}^{2} \mathrm{OCH}_{2} \mathrm{CH}_{2}\right), 4.21\left(\mathrm{t}, 2 \mathrm{H}, J=4.7 \mathrm{~Hz}, \mathrm{Ar}^{1} \mathrm{OCH}_{2} \mathrm{CH}_{2} \mathrm{NH}\right)$, $4.08\left(\mathrm{t}, J=4.7 \mathrm{~Hz}, 2 \mathrm{H}, \mathrm{CH}_{2} \mathrm{CH}_{2} \mathrm{NHO}_{2}\right), 3.88-3.80(\mathrm{~m}, 6 \mathrm{H}$, $\mathrm{OCH}_{2} \mathrm{CH}_{2} \mathrm{O}$ and $\left.\mathrm{Ar}^{1} \mathrm{OCH}_{2} \mathrm{CH}_{2} \mathrm{NH}\right), 3.82-3.50\left(\mathrm{~m}, 58 \mathrm{H}, \mathrm{OCH}_{2}\right.$ $\mathrm{CH}_{2} \mathrm{O}$ and $\left.\mathrm{N}\left(\mathrm{CH}_{2} \mathrm{CH}_{3}\right)_{2}\right), 3.38\left(\mathrm{~s}, 6 \mathrm{H}, \mathrm{OCH}_{2} \mathrm{CH}_{2} \mathrm{OCH}_{3}\right), 3.22$ $\left(\mathrm{t}, J=5.2 \mathrm{~Hz}, 2 \mathrm{H}, \mathrm{CH}_{2} \mathrm{CH}_{2} \mathrm{NHO}_{2}\right), 3.20(\mathrm{~d}, J=22.0 \mathrm{~Hz}, 2 \mathrm{H}$, $\left.\mathrm{Ar}^{1} \mathrm{CH}_{2} \mathrm{P}\right), 1.38\left(\mathrm{t}, J=7.1 \mathrm{~Hz}, 12 \mathrm{H}, \mathrm{N}\left(\mathrm{CH}_{2} \mathrm{CH}_{3}\right)_{2}\right) ;{ }^{13} \mathrm{C} \mathrm{NMR}$ (75 MHz, CD $3 \mathrm{OD}) \delta 167.8(\mathrm{NHCO}), 157.9(J=3.3 \mathrm{~Hz})(\mathrm{Ar})$, 152.1 $($ Ardye $=\mathrm{N}), 145.2(\mathrm{Ar}), 142.7$ (ArTriazole), $140.6(\mathrm{Ar}), 139.5$ (Ar), $138.1(\mathrm{Ar}), 130.8(\mathrm{~J}=8.8 \mathrm{~Hz})(\mathrm{Ar}), 130.3(\mathrm{Ar}), 128.9(\mathrm{Ar})$, 128.1 (ArTriazole), $126.5(\mathrm{Ar}), 124.7$ ( $J=9.6 \mathrm{~Hz})(\mathrm{Ar}), 120.1(\mathrm{Ar})$, 114.4 (Ar), 106.1 (Ar), 72.1 ( $\mathrm{OCH}_{2}$-ArTriazole), 71.5 (PEG), 70.7 (PEG), 70.6 (PEG), 70.5 (PEG), 70.4 (PEG), 69.4 (PEG), 69.2 (PEG), 68.5 (PEG), 67.8 (PEG), $66.1\left(\mathrm{OCH}_{2} \mathrm{CH}_{2} \mathrm{NH}\right), 62.5$ (PEG), 60.8 (PEG), $57.8\left(\mathrm{OCH}_{3}\right), 53.2\left(\right.$ ArTriazole- $\left.\mathrm{CH}_{2}\right), 48.6\left(\mathrm{~N}\left(\mathrm{CH}_{2}\right.\right.$ $\left.\left.\mathrm{CH}_{3}\right)_{2}\right), 42.8\left(\mathrm{CH}_{2} \mathrm{NHSO}_{2}\right), 39.4\left(\mathrm{CH}_{2} \mathrm{NHCOAr}\right), 32.9(\mathrm{~J}=$ $135.1 \mathrm{~Hz})(\mathrm{CH}-\mathrm{P}), 11.2\left(\mathrm{~N}\left(\mathrm{CH}_{2} \mathrm{CH}_{3}\right)_{2}\right) ;{ }^{31} \mathrm{P} \mathrm{NMR}(81 \mathrm{MHz}$, $\left.\mathrm{CD}_{3} \mathrm{OD}\right) \delta$ 26.69. MS (MALDI-TOF) $\mathrm{m} / \mathrm{z}$ calculated for $\mathrm{C}_{80} \mathrm{H}_{121} \mathrm{~N}_{7} \mathrm{O}_{28} \mathrm{PS}_{2}$ : 1722.74, obtained: 1722.61; calculated for $\mathrm{C}_{80} \mathrm{H}_{120} \mathrm{NaN}_{7} \mathrm{O}_{28} \mathrm{PS}_{2}$ : 1744.74 , obtained: 1744.63 .

Compound 56. Starting from $55(0.1 \mathrm{~g}, 0.03 \mathrm{mmol}), 56$ was obtained $(0.028 \mathrm{mmol}, 95 \%)$ as a dark yellow-green foam without further purification. ${ }^{1} \mathrm{H}$ NMR (300 $\left.\mathrm{MHz}, \mathrm{CD}_{3} \mathrm{OD}\right) \delta$ $8.68(\mathrm{~s}, 2 \mathrm{H}$, ArTriazole- $H), 8.57(\mathrm{~m}, 2 \mathrm{H}$, Ardye-2- $H), 8.08(\mathrm{~m}, 1 \mathrm{H}$, Ardye-6- $H$ ), 7.62-7.55 (d, 8H, $J=9.2 \mathrm{~Hz}$, Ardye-AA' $-H$ ), 7.48 (d, $2 \mathrm{H}, J=8.0 \mathrm{~Hz}$, Ardye-5- $H$ ), 7.38-7.30 (m, 8H, Ardye-BB' $-H), 7.27$ (s, 4H, $\left.\mathrm{Ar}^{2}-2,6-H\right), 6.53\left(\mathrm{~m}, 2 \mathrm{H}, \mathrm{Ar}^{1}-2,6-H\right), 6.45\left(\mathrm{~m}, 1 \mathrm{H}, \mathrm{Ar}^{1}-4-H\right)$, 
$5.41\left(\mathrm{~s}, 4 \mathrm{H}, \mathrm{OCH}_{2}\right.$ ArTriazole- $\left.\mathrm{CH}_{2}\right), 4.84\left(\mathrm{t}, J=4.6 \mathrm{~Hz}, 4 \mathrm{H}, \mathrm{OCH}_{2}-\right.$ ArTriazole- $\left.\mathrm{CH}_{2}\right), 4.22\left(\mathrm{~m}, 8 \mathrm{H}, \mathrm{Ar}^{2} \mathrm{OCH}_{2} \mathrm{CH}_{2}\right), 4.18-4.11(\mathrm{~m}, 4 \mathrm{H}$, $\left.\mathrm{Ar}^{1} \mathrm{OCH}_{2} \mathrm{CH}_{2} \mathrm{NH}\right), 3.98\left(\mathrm{t}, J=4.6 \mathrm{~Hz}, 4 \mathrm{H}, \mathrm{CH}_{2} \mathrm{CH}_{2} \mathrm{NHO}_{2}\right.$ ), 3.90-3.84 (m, $\left.12 \mathrm{H}, \mathrm{OCH}_{2} \mathrm{CH}_{2} \mathrm{O}, \mathrm{Ar}^{1} \mathrm{OCH}_{2} \mathrm{CH}_{2} \mathrm{NH}\right), 3.82-3.48$ $\left(\mathrm{m}, 116 \mathrm{H}, \mathrm{OCH}_{2} \mathrm{CH}_{2} \mathrm{O}\right.$ and $\left.\mathrm{N}\left(\mathrm{CH}_{2} \mathrm{CH}_{3}\right)_{2}\right), 3.32\left(\mathrm{~s}, 12 \mathrm{H}, \mathrm{OCH}_{2}-\right.$ $\mathrm{CH}_{2} \mathrm{OCH}_{3}$ ), $3.18\left(\mathrm{t}, J=5.0 \mathrm{~Hz}, 4 \mathrm{H}, \mathrm{CH}_{2} \mathrm{CH}_{2} \mathrm{NHO}_{2}\right), 3.12(\mathrm{~d}, J=$ $\left.21.5 \mathrm{~Hz}, 2 \mathrm{H}, \mathrm{Ar}^{1} \mathrm{CH}_{2} \mathrm{P}\right), 1.28\left(\mathrm{t}, J=7.0 \mathrm{~Hz}, 24 \mathrm{H}, \mathrm{N}\left(\mathrm{CH}_{2} \mathrm{CH}_{3}\right)_{2}\right) ;{ }^{13} \mathrm{C}$ NMR (75 MHz, CD $3 \mathrm{OD}) \delta 166.7$ (NHCO), 159.9 (Ar), 152.2 $($ Ardye $=\mathrm{N}), 145.7(\mathrm{Ar}), 142.6$ (ArTriazole), $140.8(\mathrm{Ar}), 139.7$ (Ar), 139.1 (Ar), 138.4 (Ar), 132.2 (Ar), 130.5 (Ar), 128.4 (Ar), 127.8 (ArTriazole), 126.6 (Ar), 124.8 (Ar), 119.1 (Ar), 108.9 (Ar), 106.2 (Ar), 72.1 ( $\mathrm{OCH}_{2}$-ArTriazole), 71.6 (PEG), 70.7 (PEG), 70.6 (PEG), 70.55 (PEG), 70.5 (PEG), 70.45 (PEG), 70.4 (PEG), 69.5 (PEG), 69.3 (PEG), 68.5 (PEG), 68.2 (PEG), $66.2\left(\mathrm{OCH}_{2} \mathrm{CH}_{2} \mathrm{NH}\right), 62.8$ (PEG), 60.7 (PEG), $57.8\left(\mathrm{OCH}_{3}\right), 52.7$ (ArTriazole- $\left.\mathrm{CH}_{2}\right), 48.5$ $\left(\mathrm{N}\left(\mathrm{CH}_{2} \mathrm{CH}_{3}\right)_{2}\right), 42.8\left(\mathrm{CH}_{2} \mathrm{NHSO}_{2}\right), 39.3\left(\mathrm{CH}_{2} \mathrm{NHCOAr}\right), 33.1(\mathrm{~J}=$ $135.2 \mathrm{~Hz})(\mathrm{CH}-\mathrm{P}), 11.2\left(\mathrm{~N}\left(\mathrm{CH}_{2} \mathrm{CH}_{2}\right)_{2}\right) ;{ }^{31} \mathrm{P} \mathrm{NMR}(81 \mathrm{MHz}$, $\left.\mathrm{CD}_{3} \mathrm{OD}\right) \delta$ 23.91. MS (MALDI-TOF) $\mathrm{m} / \mathrm{z}$ calculated for $\mathrm{C}_{152} \mathrm{H}_{229} \mathrm{~N}_{14} \mathrm{O}_{53} \mathrm{PS}_{4}$ : 3259.74, obtained: 3260.41 .

Compound 58. Starting from $57(0.22 \mathrm{~g}, 0.11 \mathrm{mmol}), 58$ was obtained ( $0.10 \mathrm{mmol}, 98 \%)$ as a dark yellow-green foam without further purification. ${ }^{1} \mathrm{H} \mathrm{NMR}\left(300 \mathrm{MHz}, \mathrm{CD}_{3} \mathrm{OD}\right) \delta 8.78(\mathrm{~s}, 1 \mathrm{H}$, ArTriazole- $H$ ), 8.55 (m, 1H, Ardye-2- $H$ ), 8.11 (m, 1H, Ardye-6- $H$ ), 7.70-7.50 (m, 9H, Ardye-5- $H$, Ardye- $\mathrm{AA}^{\prime}-H$ and Ardye- $\left.\mathrm{BB}^{\prime}-H\right)$, $7.30\left(\mathrm{~s}, 2 \mathrm{H}, \mathrm{Ar}^{2}-2,6-H\right), 6.88\left(\mathrm{~m}, 3 \mathrm{H}, \mathrm{Ar}^{1}-2,4,6-H\right), 5.51(\mathrm{~s}, 2 \mathrm{H}$, $\mathrm{OCH}_{2}$ ArTriazole- $\left.\mathrm{CH}_{2}\right), 4.91\left(\mathrm{~m}, 2 \mathrm{H}, \mathrm{OCH}_{2}\right.$ ArTriazole- $\left.\mathrm{CH}_{2}\right), 4.30$ $\left(\mathrm{m}, 4 \mathrm{H}, \mathrm{Ar}^{2} \mathrm{OCH}_{2} \mathrm{CH}_{2}\right), 4.26\left(\mathrm{~m}, 2 \mathrm{H}, \mathrm{Ar}^{1} \mathrm{OCH}_{2} \mathrm{CH}_{2} \mathrm{NH}\right), 4.04$ (m, 2H, $\left.\mathrm{CH}_{2} \mathrm{CH}_{2} \mathrm{NHO}_{2}\right), 3.90-3.82\left(\mathrm{~m}, 6 \mathrm{H}, \mathrm{OCH}_{2} \mathrm{CH}_{2} \mathrm{O}\right.$ and $\left.\mathrm{Ar}^{1} \mathrm{OCH}_{2} \mathrm{CH}_{2} \mathrm{NH}\right), 3.82-3.50\left(\mathrm{~m}, 58 \mathrm{H}, \mathrm{OCH}_{2} \mathrm{CH}_{2} \mathrm{O}\right.$ and $\mathrm{N}\left(\mathrm{CH}_{2}-\right.$ $\left.\left.\mathrm{CH}_{3}\right)_{2}\right), 3.31\left(\mathrm{~s}, 6 \mathrm{H}, \mathrm{OCH}_{2} \mathrm{CH}_{2} \mathrm{OCH}_{3}\right), 3.21(\mathrm{~d}, J=22.0 \mathrm{~Hz}, 4 \mathrm{H}$, $\left.\mathrm{Ar}^{1} \mathrm{CH}_{2} \mathrm{P}\right), 3.19\left(\mathrm{~m}, 2 \mathrm{H}, \mathrm{CH}_{2} \mathrm{CH}_{2} \mathrm{NHO}_{2}\right), 1.32\left(\mathrm{~m}, 12 \mathrm{H}, \mathrm{N}\left(\mathrm{CH}_{2}-\right.\right.$ $\left.\mathrm{CH}_{3}\right)_{2}$ ); ${ }^{13} \mathrm{C} \mathrm{NMR}\left(75 \mathrm{MHz}, \mathrm{CD}_{3} \mathrm{OD}\right) \delta 167.8$ (NHCO), $158.8(\mathrm{Ar})$, 152.1 $($ Ardye $=\mathrm{N}), 142.7($ ArTriazole), $140.4(\mathrm{Ar}), 139.5(\mathrm{Ar}), 138.3$ (Ar), 133.2 (Ar), 131.1 (Ar), 130.4 (Ar), 128.9 (Ar), 128.1 (Ar), 127.5 (ArTriazole), 126.2 (Ar), 123.7 (Ar), 123.3 (Ar), 120.2 (Ar), 114.8 (Ar), 106.2 (Ar), 72.1 ( $\mathrm{OCH}_{2}$-ArTriazole), 71.5 (PEG), 70.7 (PEG), 70.6 (PEG), 70.5 (PEG), 70.4 (PEG), 69.4 (PEG), 69.2 (PEG), 68.5 (PEG), 67.8 (PEG), $66.1\left(\mathrm{OCH}_{2} \mathrm{CH}_{2} \mathrm{NH}\right.$ ), 62.5 (PEG), 60.9 (PEG), 57.8 (OCH3), 53.8 (ArTriazole- $\mathrm{CH} 2), 48.4\left(\mathrm{~N}\left(\mathrm{CH}_{2} \mathrm{CH}_{3}\right)_{2}\right), 42.6$ $\left(\mathrm{CH}_{2} \mathrm{NHSO}_{2}\right), 39.5\left(\mathrm{CH}_{2} \mathrm{NHCOAr}\right), 33.8(\mathrm{~J}=135.1 \mathrm{~Hz})(C \mathrm{H}-\mathrm{P})$, $11.2\left(\mathrm{~N}\left(\mathrm{CH}_{2} \mathrm{CH}_{3}\right)_{2}\right) ;{ }^{31} \mathrm{P} \mathrm{NMR}\left(81 \mathrm{MHz}, \mathrm{CD}_{3} \mathrm{OD}\right) \delta$ 24.21. MS (MALDI-TOF) $m / z$ calculated for $\mathrm{C}_{81} \mathrm{H}_{123} \mathrm{NaN}_{7} \mathrm{O}_{31} \mathrm{P}_{2} \mathrm{~S}_{2}$ : 1838.72, obtained: 1838.64 .

Compound 60. Starting from 59 (0.2 g, $0.06 \mathrm{mmol}), 60$ was obtained $(0.058 \mathrm{mmol}, 98 \%)$ as a dark yellow-green foam without further purification. ${ }^{1} \mathrm{H}$ NMR $\left(300 \mathrm{MHz}, \mathrm{CD}_{3} \mathrm{OD}\right) \delta$ $8.82(\mathrm{~m}, 2 \mathrm{H}$, Ardye-2- $H$ ), 8.58 (s, 2H, ArTriazole- $H$ ), $8.14(\mathrm{~m}, \mathrm{H}$, Ardye-6- $H$ ), 7.72-7.47 (m, 18H, Ardye-5- $H$, Ardye-AA'- $H$ and Ardye-BB'- $H$ ), 7.31 (s, 4H, Ar3-2,6-H), 7.11 (m, 2H, Ar2-2,6- $H$ ), 6.95-6.88 (m, 3H, $\left.\mathrm{Ar}^{1}-2,4,6-H\right), 6.75\left(\mathrm{~m}, 1 \mathrm{H}, \mathrm{Ar}^{2}-4-H\right), 5.48(\mathrm{~s}, 4 \mathrm{H}$, $\mathrm{OCH}_{2}$ ArTriazole- $\left.\mathrm{CH}_{2}\right), 4.91\left(\mathrm{~m}, 4 \mathrm{H}, \mathrm{OCH}_{2}\right.$ ArTriazole- $\left.\mathrm{CH}_{2}\right), 4.30-$ $4.15\left(\mathrm{~m}, 14 \mathrm{H}, \mathrm{Ar}^{1} \mathrm{OCH}_{2} \mathrm{CH}_{2} \mathrm{NH}, \mathrm{Ar}^{2} \mathrm{OCH}_{2} \mathrm{CH}_{2} \mathrm{NH}\right.$ and $\mathrm{Ar}^{2} \mathrm{OCH}_{2}-$ $\mathrm{CH}_{2}$ ), $4.02\left(\mathrm{~m}, 4 \mathrm{H}, \mathrm{CH}_{2} \mathrm{CH}_{2} \mathrm{NHO}_{2}\right), 3.85-3.70\left(\mathrm{~m}, 14 \mathrm{H}, \mathrm{OCH}_{2}-\right.$ $\mathrm{CH}_{2} \mathrm{O}, \mathrm{Ar}^{1} \mathrm{OCH}_{2} \mathrm{CH}_{2} \mathrm{NH}$ and $\left.\mathrm{Ar}^{2} \mathrm{OCH}_{2} \mathrm{CH}_{2} \mathrm{NH}\right), 3.75-3.45(\mathrm{~m}, 116 \mathrm{H}$, $\mathrm{OCH}_{2} \mathrm{CH}_{2} \mathrm{O}$ and $\left.\mathrm{N}\left(\mathrm{CH}_{2} \mathrm{CH}_{3}\right)_{2}\right), 3.34\left(\mathrm{~s}, 12 \mathrm{H}, \mathrm{OCH}_{2} \mathrm{CH}_{2} \mathrm{OCH}_{3}\right)$, 3.22-3.12 (m, 8H, $\mathrm{CH}_{2} \mathrm{CH}_{2} \mathrm{NHO}_{2}$ and $\left.\mathrm{Ar}^{1} \mathrm{CH}_{2} \mathrm{P}\right), 1.32(\mathrm{~m}, 24 \mathrm{H}$,
$\left.\mathrm{N}\left(\mathrm{CH}_{2} \mathrm{CH}_{3}\right)_{2}\right)$; 13C NMR (75 MHz, $\left.\mathrm{CD}_{3} \mathrm{OD}\right) \delta 167.8(\mathrm{NHCO}), 159.9$ $(\mathrm{Ar}), 158.6(\mathrm{Ar}), 151.9($ Ardye $=\mathrm{N}), 145.0(\mathrm{Ar}), 142.2$ (ArTriazole), 140.0 (Ar), 139.5 (Ar), 138.3 (Ar), 135.5 (Ar), 133.4 (Ar), 131.8 (Ar), 130.1 (Ar), 128.3 (Ar), 127.9 (ArTriazole), 126.2 (Ar), 119.3 (Ar), 114.1 (Ar), 105.5 (Ar), 104.2 (Ar), $71.5\left(\mathrm{OCH}_{2}\right.$-ArTriazole), 71.3 (PEG), 70.7 (PEG), 70.6 (PEG), 70.5 (PEG), 70.4 (PEG), 69.4 (PEG), 69.2 (PEG), 68.5 (PEG), 67.8 (PEG), 66.8 ( $\left.\mathrm{OCH}_{2} \mathrm{CH}_{2} \mathrm{NH}\right), 62.1$ (PEG), 60.2 (PEG), $57.1\left(\mathrm{OCH}_{3}\right), 53.2$ (ArTriazole- $\left.\mathrm{CH}_{2}\right), 48.4\left(\mathrm{~N}\left(\mathrm{CH}_{2} \mathrm{CH}_{3}\right)_{2}\right), 42.3$ $\left(\mathrm{CH}_{2} \mathrm{NHSO}_{2}\right), 38.8\left(\mathrm{CH}_{2} \mathrm{NHCOAr}\right), 33.8(\mathrm{~J}=135.1 \mathrm{~Hz})(\mathrm{CH}-\mathrm{P})$, $10.7\left(\mathrm{~N}\left(\mathrm{CH}_{2} \mathrm{CH}_{3}\right)_{2}\right) ;{ }^{31} \mathrm{P} \mathrm{NMR}\left(81 \mathrm{MHz}, \mathrm{CD}_{3} \mathrm{OD}\right) \delta$ 25.11. MS (MALDI-TOF) $\mathrm{m} / \mathrm{z}$ calculated for $\mathrm{C}_{163} \mathrm{H}_{243} \mathrm{~N}_{15} \mathrm{O}_{58} \mathrm{P}_{2} \mathrm{~S}_{4}$ : 3530.95, obtained: 3530.84 .

\section{Part II: click-chemistry with phosphonates}

Compound 67. Sodium azide $(0.9 \mathrm{~g}, 13.9 \mathrm{mmol})$ was added to a solution of $66(1.92 \mathrm{~g}, 6.94 \mathrm{mmol})$ in $\mathrm{CH}_{3} \mathrm{CN}(35 \mathrm{~mL})$ and the resulting mixture was refluxed for $16 \mathrm{~h}$. The solvent was then removed under pressure and the residue dissolved in water. The aqueous phase was washed with EtOAc and the organic layer was dried over $\mathrm{MgSO}_{4}$, filtered and concentrated in vacuo to yield 67 (6.56 mmol, 95\%) as yellow oil. ${ }^{1} \mathrm{H}$ NMR $\left(300 \mathrm{MHz}, \mathrm{CDCl}_{3}\right) \delta 7.35-7.25(\mathrm{~m}, 4 \mathrm{H}, \mathrm{Ar}), 4.32\left(\mathrm{~s}, 2 \mathrm{H}, \mathrm{CH}_{2} \mathrm{~N}_{3}\right)$, 4.01 (qt, $4 \mathrm{H}, J=6.99 \mathrm{~Hz}, \mathrm{CH}_{2} \mathrm{CH}_{3}$ ), $3.20(\mathrm{~d}, 4 \mathrm{H}, J=21.7 \mathrm{~Hz}$, $\mathrm{CH}_{2} \mathrm{PO}(\mathrm{OEt})_{2}$ ), 1.25 (dd, $3 \mathrm{H}, J=7.02$ and $\left.6.99 \mathrm{~Hz}, \mathrm{CH}_{3}\right) ;{ }^{13} \mathrm{C}$ NMR $\left(75 \mathrm{MHz}, \mathrm{CDCl}_{3}\right) \delta 133.8\left(J=3.84 \mathrm{~Hz}, \mathrm{C}\right.$ Ar next to $\left.\mathrm{CH}_{2} \mathrm{~N}_{3}\right)$, $131.8\left(J=9.27 \mathrm{~Hz}, \mathrm{C}\right.$ Ar next to $\left.\mathrm{CH}_{2} \mathrm{PO}(\mathrm{OEt})_{2}\right), 130.0(\mathrm{~J}=$ $6.54 \mathrm{~Hz}, \mathrm{CH}$ Ar next to $\left.\mathrm{CH}_{2} \mathrm{PO}(\mathrm{OEt})_{2}\right), 128.2(J=2.72 \mathrm{~Hz}, \mathrm{CH}$ Ar next to $\left.\mathrm{CH}_{2} \mathrm{~N}_{3}\right), 61.9\left(\mathrm{~J}=6.54 \mathrm{~Hz}, \mathrm{CH}_{2} \mathrm{CH}_{3}\right), 54.1\left(\mathrm{CH}_{2} \mathrm{~N}_{3}\right)$, 34.1, 32.3 (d, $\left.J=136.9 \mathrm{~Hz}, C \mathrm{H}_{2} \mathrm{PO}(\mathrm{OEt})_{2}\right), 16.1(J=6.54 \mathrm{~Hz}$, $\mathrm{CH}_{3}$ ); ${ }^{31} \mathrm{P}$ NMR (81 MHz, $\mathrm{CDCl}_{3}$ ) $\delta$ 26.48; MS (MALDI-TOF) $\mathrm{m} / \mathrm{z}$ calculated for $\mathrm{C}_{12} \mathrm{H}_{18} \mathrm{~N}_{303} \mathrm{P} 283.11$, obtained $[\mathrm{M}+\mathrm{H}]^{+}=284.13$.

Compound 72. The preparation procedures and analytical data are similar to those reported in the literature. ${ }^{22 c}$

Compound 81. Propargylbromide (2.1 mL, $19 \mathrm{mmol})$ was added to a solution of $21(6.2 \mathrm{~g}, 16 \mathrm{mmol})$ and $\mathrm{K}_{2} \mathrm{CO}_{3}(22.0 \mathrm{~g}, 160 \mathrm{mmol})$ in acetone $(150 \mathrm{~mL})$. A pinch of 18-crown- 6 was added and the resulting mixture was refluxed for $16 \mathrm{~h}$. The solvent was then removed in vacuo after filtration. The crude product was dissolved in $\mathrm{CH}_{2} \mathrm{Cl}_{2}$ and the organic phase was washed with water, brine, dried over $\mathrm{MgSO}_{4}$, filtered and concentrated in vacuo to yield $\mathbf{8 1}$ (13.4 mmol, 84\%). Colourless oil. ${ }^{1} \mathrm{H}$ NMR (300 MHz, $\left.\mathrm{CDCl}_{3}\right) \delta 6.85-$ $6.83\left(\mathrm{~m}, 3 \mathrm{H}, \mathrm{H} \mathrm{Ar}\right.$ ), 4.67 (d, 2H, $J=2.19 \mathrm{~Hz}, \mathrm{CH}_{2}$ alkyne), 4.02 (qt, 8H, $\left.J=6.99 \mathrm{~Hz}, \mathrm{CH}_{2} \mathrm{CH}_{3}\right), 3.14,3.06\left(\mathrm{~d}, 2 \mathrm{H}, J=21.93 \mathrm{~Hz}, \mathrm{CH}_{2} \mathrm{PO}(\mathrm{OEt})_{2}\right)$, 2.50 (dd, $1 \mathrm{H}, J=2.43$ and $2.40 \mathrm{~Hz}, \mathrm{H}$ alkyne), 1.25 (dd, $12 \mathrm{H}, J=4.59$ and $\left.7.02 \mathrm{~Hz}, \mathrm{CH}_{3}\right) ;{ }^{13} \mathrm{C}$ NMR (75 MHz, $\left.\mathrm{CDCl}_{3}\right) \delta 157.6$ (C Ar next to alkyne), $133.1\left(J=11.45 \mathrm{~Hz}, \mathrm{C}\right.$ Ar next to $\left.\mathrm{CH}_{2} \mathrm{PO}(\mathrm{OEt})_{2}\right), 124.4$ $\left(J=13.09 \mathrm{~Hz}, \mathrm{CH}\right.$ Ar next to $\left.\mathrm{CH}_{2} \mathrm{PO}(\mathrm{OEt})_{2}\right), 114.8(J=8.72 \mathrm{~Hz}, \mathrm{CH} \mathrm{Ar}$ next to alkyne), 78.3 (C alkyne), 75.4 (CH alkyne), 61.9 ( $J=7.63 \mathrm{~Hz}$, $\mathrm{CH}_{2} \mathrm{CH}_{3}$ ), 55.7 ( $\mathrm{CH}_{2}$ alkyne), 34.5, 32.6 ( $\mathrm{J}=137.46 \mathrm{~Hz}, \mathrm{CH}_{2} \mathrm{PO}-$ $\left.(\mathrm{OEt})_{2}\right), 16.2\left(\mathrm{~J}=5.45 \mathrm{~Hz}, \mathrm{CH}_{3}\right) ;{ }^{31} \mathrm{P} \mathrm{NMR}\left(81 \mathrm{MHz}, \mathrm{CDCl}_{3}\right) \delta 26.63$; MS (MALDI-TOF) $\mathrm{m} / \mathrm{z}$ calculated for $\mathrm{C}_{19} \mathrm{H}_{30} \mathrm{O}_{7} \mathrm{P}_{2} 432.14$, obtained $[\mathrm{M}+\mathrm{H}]^{+}=434.12,[\mathrm{M}+\mathrm{Na}]^{+}=455.09$.

\section{Bisphosphonic acid anchors final deprotection}

The pegylated PAMAM dendrons were deprotected in the last step to give the bisphosphonic acid anchors necessary for 
grafting onto nanoparticles. For dendron 75, two steps were necessary to get the $\mathrm{OH}$-functionalized bisphosphonic acid $\mathbf{9 2}$. On the other hand, for dendrons 73, 74, 79, 80, 86, 87, 90 and 91, one step was enough to deprotect both of the esters and obtain $\mathrm{COOH}$-functionalized bisphosphonic acids 93-100.

Compound 92. A solution of tetrabutylammonium fluoride (TBAF, $1 \mathrm{M}$ ) in THF (1.6 mL, $0.17 \mathrm{mmol})$ was added to a solution of $75(0.85 \mathrm{~g}, 0.58 \mathrm{mmol})$ in THF $(6 \mathrm{~mL})$. The reaction mixture was stirred for $16 \mathrm{~h}$ at room temperature and quenched with acetic acid $(140 \mu \mathrm{L})$. The solvent was then removed in vacuo. The crude product was directly purified by column chromatography $\left(\mathrm{SiO}_{2}, \mathrm{CH}_{2} \mathrm{Cl}_{2} / \mathrm{MeOH} 90: 10-80: 20\right)$ to yield the corresponding protected dialcohol (0.53 mmol, 75\%). Yellow oil. ${ }^{1} \mathrm{H}$ NMR (300 $\left.\mathrm{MHz}, \mathrm{CDCl}_{3}\right) \delta 7.74(\mathrm{~m}, 2 \mathrm{H}, \mathrm{NH})$, 7.59 (s, 1H, H triazole), 7.20-7.11 (m, 3H, H Ar), $5.48(\mathrm{~s}, 2 \mathrm{H}$, $\mathrm{CH}_{2} \mathrm{~N}$ next to triazole), 4.00 (qt, $8 \mathrm{H}, J=7.23 \mathrm{~Hz}, \mathrm{CH}_{2} \mathrm{CH}_{3}$ ), 3.813.51 (m, 30H, PEG, $\mathrm{NCH}_{2}$ PAMAM, $\mathrm{CH}_{2} \mathrm{~N}$ PAMAM), 3.52 (q, $4 \mathrm{H}$, $J=5.25$ and $\left.10.53 \mathrm{~Hz}, \mathrm{CH}_{2} \mathrm{OH}\right), 3.14,3.07(\mathrm{~d}, 2 \mathrm{H}, J=21.93 \mathrm{~Hz}$, $\mathrm{CH}_{2} \mathrm{PO}(\mathrm{OEt})_{2}$ ), 2.75 (dd, $4 \mathrm{H}, J=6.36$ and $6.57 \mathrm{~Hz}, \mathrm{CONHCH}_{2}$ ), $2.41\left(\mathrm{dd}, 4 \mathrm{H}, J=6.36\right.$ and $\left.6.33 \mathrm{~Hz}, \mathrm{CH}_{2} \mathrm{CONH}\right), 1.23(\mathrm{t}, 12 \mathrm{H}$, $\left.J=7.02 \mathrm{~Hz}, \mathrm{CH}_{3}\right) ;{ }^{13} \mathrm{C} \mathrm{NMR}\left(75 \mathrm{MHz}, \mathrm{CDCl}_{3}\right) \delta 171.1(\mathrm{CONH})$, $143.0(J=6.50 \mathrm{~Hz}, \mathrm{C}$ Ar next to triazole), $134.4(J=11.91 \mathrm{~Hz}, \mathrm{C}$ Ar next to $\left.\mathrm{CH}_{2} \mathrm{PO}(\mathrm{OEt})_{2}\right), 132.0(J=13.00 \mathrm{~Hz}, \mathrm{CH}$ Ar next to $\left.\mathrm{CH}_{2} \mathrm{PO}(\mathrm{OEt})_{2}\right), 130.4$ (C alkyne), $127.0(\mathrm{~J}=9.21 \mathrm{~Hz}, \mathrm{CH}$ Ar next to triazole), 122.3 ( $\mathrm{CH}$ alkyne), $72.1\left(\mathrm{CH}_{2} \mathrm{CH}_{2} \mathrm{OH}\right), 70.0$ (PEG), 69.9 (PEG), 69.6 (PEG), 69.5 (PEG), 69.3 (PEG), 61.7 ( $J=7.05 \mathrm{~Hz}$, $\left.\mathrm{CH}_{2} \mathrm{CH}_{3}\right), 60.8\left(\mathrm{CH}_{2} \mathrm{OH}\right), 53.2\left(\mathrm{CH}_{2} \mathrm{~N}\right.$ next to triazole), 48.9 ( $\mathrm{NCH}_{2}$ PAMAM), $47.4\left(\mathrm{CH}_{2} \mathrm{~N}\right.$ PAMAM), $38.7\left(\mathrm{CH}_{2} \mathrm{CONH}\right), 33.9$, 32.1 (d, $\left.J=136.54 \mathrm{~Hz}, \mathrm{CH}_{2} \mathrm{PO}(\mathrm{OEt}) 2\right), 33.3\left(\mathrm{CONHCH}_{2}\right), 16.2$ $\left(J=5.96 \mathrm{~Hz}, \mathrm{CH}_{3}\right)$. An excess of bromotrimethylsilane (TMSBr, $2 \mathrm{~mL}, 15.3 \mathrm{mmol}$ ) was then added at room temperature to a solution of bisphosphonate ester $(0.51 \mathrm{~g}, 0.52 \mathrm{mmol})$ in $\mathrm{CH}_{2} \mathrm{Cl}_{2}$ $(5 \mathrm{~mL})$. The reaction mixture was stirred for $2 \mathrm{~h}$ then quenched with $\mathrm{MeOH}$. The solvent was evaporated under vacuum to give 92 (0.51 mmol, quant) without further purification. ${ }^{1} \mathrm{H}$ NMR (300 MHz, $\left.\mathrm{CD}_{3} \mathrm{OD}\right) \delta 8.33(\mathrm{~s}, 1 \mathrm{H}, \mathrm{H}$ triazole), 7.27-7.21 (m, $3 \mathrm{H}$, $\mathrm{H}$ Ar), $5.66\left(\mathrm{~s}, 2 \mathrm{H}, \mathrm{CH}_{2} \mathrm{~N}\right.$ next to triazole), $5.66\left(\mathrm{~s}, 2 \mathrm{H}, \mathrm{CH}_{2} \mathrm{~N}\right.$ PAMAM), 3.69-3.38 (m, 32H, PEG, $\mathrm{NCH}_{2}$ PAMAM, $\mathrm{CH}_{2} \mathrm{OH}$ ), 3.19, $3.12\left(\mathrm{~d}, 2 \mathrm{H}, J=21.93 \mathrm{~Hz}, \mathrm{CH}_{2} \mathrm{PO}(\mathrm{OH})_{2}\right), 2.86(\mathrm{~m}, 4 \mathrm{H}$, $\left.\mathrm{CONHCH}_{2}\right), 2.67\left(\mathrm{~m}, 4 \mathrm{H}, \mathrm{CH}_{2} \mathrm{CONH}\right) ;{ }^{13} \mathrm{C} \mathrm{NMR}(75 \mathrm{MHz}$, $\left.\mathrm{CD}_{3} \mathrm{OD}\right) \delta 171.9$ (CONH), 136.7 (C Ar next to triazole), 134.2 (C Ar next to $\mathrm{CH}_{2} \mathrm{PO}(\mathrm{OH})_{2}$ ), 132.3 ( $\mathrm{CH}$ Ar next to $\mathrm{CH}_{2} \mathrm{PO}(\mathrm{OH})_{2}$, C alkyne), 129.1 ( $\mathrm{CH}$ Ar next to triazole, $\mathrm{CH}$ alkyne), 73.1 $\left(\mathrm{CH}_{2} \mathrm{CH}_{2} \mathrm{OH}\right), 70.9$ (PEG), 70.8 (PEG), 69.9 (PEG), $61.9\left(\mathrm{CH}_{2} \mathrm{OH}\right)$, $54.6\left(\mathrm{CH}_{2} \mathrm{~N}\right.$ next to triazole), $50.86\left(\mathrm{NCH}_{2}\right.$ PAMAM), $47.5\left(\mathrm{CH}_{2} \mathrm{~N}\right.$ PAMAM), 40.3 ( $\left.\mathrm{CH}_{2} \mathrm{CONH}\right), 35.5,33.7$ (d, $4 \mathrm{H}, J=134.18 \mathrm{~Hz}$, $\left.\mathrm{CH}_{2} \mathrm{PO}(\mathrm{OH})_{2}\right), 29.9\left(\mathrm{CONHCH}_{2}\right) ;{ }^{31} \mathrm{P} \mathrm{NMR}\left(81 \mathrm{MHz}, \mathrm{CD}_{3} \mathrm{OD}\right)$ $\delta$ 25.76; MS (MALDI-TOF) $m / z$ calculated for $\mathrm{C}_{34} \mathrm{H}_{60} \mathrm{~N}_{6} \mathrm{O}_{16} \mathrm{P}_{2}$ 870.35 , obtained $[\mathrm{M}+\mathrm{H}]^{+}=871.31$.

General procedure for the conversion of phosphonate ester to phosphonic acid by TMSBr (McKenna's method ${ }^{28}$ ) (93-100)

TMSBr (30 equiv.) was added at room temperature to a solution of bisphosphonate ester 73, 74, 79, 80, 86, 87, 90 or 91 (1 equiv.) in $\mathrm{CH}_{2} \mathrm{Cl}_{2}(5 \mathrm{~mL})$. The reaction mixture was stirred for $2 \mathrm{~h}$ then quenched with $\mathrm{MeOH}$. The solvent was evaporated under vacuum 3 times to give the desired compound without further purification.

Compound 93. Starting from $73(0.15 \mathrm{~g}, 0.14 \mathrm{mmol})$, compound 93 was obtained $(0.13 \mathrm{mmol}, 98 \%)$. Yellow oil. ${ }^{1} \mathrm{H}$ NMR (300 MHz, $\left.\mathrm{CD}_{3} \mathrm{OD}\right) \delta 8.46(\mathrm{~s}, 1 \mathrm{H}, \mathrm{CH}$ triazole), 7.36 (s, 4H, Ar), $5.68\left(\mathrm{~s}, 2 \mathrm{H}, \mathrm{CH}_{2} \mathrm{~N}\right.$ triazole), $4.66\left(\mathrm{~s}, 2 \mathrm{H}, \mathrm{CH}_{2} \mathrm{~N}\right.$ PAMAM), 3.74 (dd, $4 \mathrm{H}, J=6.15$ and $5.91 \mathrm{~Hz}, \mathrm{CH}_{2} \mathrm{CH}_{2} \mathrm{COOH}$ ), 3.70-3.34 (m, 36H, PEG), 3.25, 3.18 (d, 2H, $J=21.93 \mathrm{~Hz}, \mathrm{CH}_{2} \mathrm{PO}(\mathrm{OH})_{2}$ ), $2.62\left(\mathrm{dd}, 4 \mathrm{H}, J=5.19\right.$ and $\left.6.12 \mathrm{~Hz}, \mathrm{CH}_{2} \mathrm{COOH}\right) ;{ }^{13} \mathrm{C} \mathrm{NMR}$ $\left(75 \mathrm{MHz}, \mathrm{CDCl}_{3}\right) \delta 172.4(\mathrm{COOH}), 170.7(\mathrm{CONH}), 135.9(\mathrm{C} \mathrm{Ar}$ next to triazole), $133.7\left(J=2.73 \mathrm{~Hz}, \mathrm{C}\right.$ Ar next to $\left.\mathrm{CH}_{2} \mathrm{PO}(\mathrm{OH})_{2}\right)$, 133.1 (C triazole), $130.3\left(\mathrm{~J}=6 \mathrm{~Hz}, \mathrm{CH}\right.$ Ar next to $\mathrm{CH}_{2} \mathrm{PO}(\mathrm{OH})_{2}$ ), $128.1(J=2.18 \mathrm{~Hz}, \mathrm{CH}$ Ar next to triazole), 127.3 ( $\mathrm{CH}$ Ar next to triazole), 127.3 (CH triazole), 70.2 (PEG), 70.1 (PEG), 70.0 (PEG), 69.9 (PEG), $69.0\left(\mathrm{CONHCH}_{2} \mathrm{CH}_{2} \mathrm{O}\right), 66.3\left(\mathrm{CH}_{2} \mathrm{CH}_{2} \mathrm{COOH}\right), 53.5$ $\left(\mathrm{CH}_{2} \mathrm{~N}\right.$ PAMAM), $49.9\left(\mathrm{CH}_{2} \mathrm{~N}\right.$ triazole), $46.4\left(\mathrm{NCH}_{2}\right.$ PAMAM), $39.1\left(\mathrm{CONHCH}_{2}\right), 34.3\left(\mathrm{CH}_{2} \mathrm{COOH}\right), 34.4,32.9(\mathrm{~J}=133.64 \mathrm{~Hz}$, $\left.\mathrm{CH}_{2} \mathrm{PO}(\mathrm{OH})_{2}\right), 28.6\left(\mathrm{CH}_{2} \mathrm{COOH}\right) ;{ }^{31} \mathrm{P} \mathrm{NMR}\left(81 \mathrm{MHz}, \mathrm{CD}_{3} \mathrm{OD}\right)$ $\delta$ 25.10; MS (MALDI-TOF) $\mathrm{m} / \mathrm{z}$ calculated for 920.41 , obtained $[\mathrm{M}+\mathrm{H}]^{+}=921.36$.

Compound 94. The preparation procedures and analytical data are reported in the literature. ${ }^{22 c}$

Compound 95. Starting from 79 (0.19 g, $0.29 \mathrm{mmol})$, compound 95 was obtained $(0.29 \mathrm{mmol}, 98 \%)$ as an yellow oil. ${ }^{1} \mathrm{H}$ NMR (300 MHz, CD $\left.\mathrm{OD}\right) \delta 8.41$ (s, 1H, H triazole), $7.31(\mathrm{~m}, 3 \mathrm{H}$, $\mathrm{H} \mathrm{Ar}$ ), 5.73 (s, 2H, $\mathrm{CH}_{2} \mathrm{~N}$ next to triazole), 4.76 (s, $2 \mathrm{H}, \mathrm{CH}_{2} \mathrm{O}$ next to triazole), 3.73-3.52 (m, 12H, PEG), 3.35 (s, 3H, $\left.\mathrm{OCH}_{3}\right), 3.25,2.18$ $\left(\mathrm{d}, 4 \mathrm{H}, J=21.93 \mathrm{~Hz}, \mathrm{CH}_{2} \mathrm{PO}(\mathrm{OH})_{2}\right) ;{ }^{13} \mathrm{C} \mathrm{NMR}\left(75 \mathrm{MHz}, \mathrm{CD}_{3} \mathrm{OD}\right)$ $\delta 141.6$ (C triazole), 134.0 ( $J=10.16 \mathrm{~Hz}, \mathrm{C}$ Ar next to triazole), 132.8 (C Ar next to $\left.\mathrm{CH}_{2} \mathrm{PO}(\mathrm{OH})_{2}\right), 131.7(\mathrm{~J}=11.77 \mathrm{~Hz}, \mathrm{CH}$ Ar next to $\left.\mathrm{CH}_{2} \mathrm{PO}(\mathrm{OH})_{2}\right), 128.2(\mathrm{~J}=8.55 \mathrm{~Hz}, \mathrm{CH}$ Ar next to triazole $), 126.2(\mathrm{CH}$ triazole), $73.0\left(\mathrm{CH}_{2} \mathrm{OCH}_{3}\right), 72.3$ (PEG), 71.2 (PEG), 71.1 (PEG), 69.8 (PEG), 71.0 (PEG), 70.9 (PEG), 70.8 (PEG), 70.7 (PEG), $62.6\left(\mathrm{CH}_{2}\right.$ $\mathrm{OCH}_{2} \mathrm{CH}_{2} \mathrm{O}$ next to triazole), $61.8\left(\mathrm{CH}_{2} \mathrm{O}\right.$ next to triazole), 58.8 $\left(\mathrm{OCH}_{3}\right), 57.0\left(\mathrm{CH}_{2} \mathrm{~N}\right.$ next to triazole), 36.4, 34.7 (d, $J=131.07 \mathrm{~Hz}$, $\mathrm{CH}_{2} \mathrm{PO}(\mathrm{OH})_{2}$ ); ${ }^{31} \mathrm{P}$ NMR (81 MHz, $\left.\mathrm{CD}_{3} \mathrm{OD}\right) \delta$ 25.15; MS (MALDITOF) $m / z$ calculated for $\mathrm{C}_{19} \mathrm{H}_{31} \mathrm{~N}_{3} \mathrm{O}_{10} \mathrm{P}_{2} 523.14$, obtained $[\mathrm{M}+\mathrm{H}]^{+}=$ 524.03, $[\mathrm{M}+\mathrm{Na}]^{+}=545.99,[\mathrm{M}+\mathrm{K}]^{+}=561.94$.

Compound 96. Starting from $80(0.17 \mathrm{~g}, 0.18 \mathrm{mmol})$, compound 96 was obtained $(0.18 \mathrm{mmol}, 99 \%)$ as an orange oil. ${ }^{1} \mathrm{H}$ NMR (300 MHz, $\left.\mathrm{CD}_{3} \mathrm{OD}\right) \delta 8.67$ (s, 1H, CH triazole), 7.36 (s, $3 \mathrm{H}, \mathrm{H} \mathrm{Ar}), 5.86\left(\mathrm{~s}, 2 \mathrm{H}, \mathrm{CH}_{2} \mathrm{~N}\right.$ next to triazole), $4.84(\mathrm{~s}, 2 \mathrm{H}$, $\mathrm{CH}_{2} \mathrm{O}$ triazole), 3.77-3.52 (m, 36H, PEG), $3.35\left(\mathrm{~s}, 3 \mathrm{H}, \mathrm{OCH}_{3}\right.$ ), $3.25,3.18\left(\mathrm{~d}, 4 \mathrm{H}, J=21.93 \mathrm{~Hz}, \mathrm{CH}_{2} \mathrm{PO}(\mathrm{OH})_{2}\right), 2.57(\mathrm{t}, 2 \mathrm{H}, J=6.15$ $\left.\mathrm{Hz}, \mathrm{CH}_{2} \mathrm{COOH}\right) ;{ }^{13} \mathrm{C} \mathrm{NMR}\left(75 \mathrm{MHz}, \mathrm{CD}_{3} \mathrm{OD}\right) \delta 141.7$ (C triazole), $134.0(J=9.09 \mathrm{~Hz}, \mathrm{C}$ Ar next to triazole), 132.9 (C Ar next to $\left.\mathrm{CH}_{2} \mathrm{PO}(\mathrm{OH})_{2}\right), 131.8\left(J=5.34 \mathrm{~Hz}, \mathrm{CH}\right.$ Ar next to $\left.\mathrm{CH}_{2} \mathrm{PO}(\mathrm{OH})_{2}\right)$, 128.3 ( $\mathrm{CH}$ Ar next to triazole), 126.4 ( $\mathrm{CH}$ triazole), 73.0 $\left(\mathrm{CH}_{2} \mathrm{OCH}_{3}\right.$ ), 72.4 (PEG), 71.2 (PEG), 70.9 (PEG), 70.9 (PEG), $62.6\left(\mathrm{CH}_{2} \mathrm{OCH}_{2} \mathrm{CH}_{2} \mathrm{O}\right.$ next to triazole $), 61.9\left(\mathrm{CH}_{2} \mathrm{O}\right.$ next to triazole), $58.9\left(\mathrm{OCH}_{3}\right), 57.0\left(\mathrm{CH}_{2} \mathrm{~N}\right.$ next to triazole $), 36.5,34.7$ (d, $\left.J=130.53 \mathrm{~Hz}, \mathrm{CH}_{2} \mathrm{PO}(\mathrm{OH})_{2}\right) ;{ }^{31} \mathrm{P}$ NMR (81 MHz, $\mathrm{CD}_{3} \mathrm{OD}$ ) $\delta$ 25.08; MS (MALDI-TOF) $m / z$ calculated for $\mathrm{C}_{31} \mathrm{H}_{55} \mathrm{~N}_{3} \mathrm{O}_{16} \mathrm{P}_{2}$ 787.30, obtained $[\mathrm{M}+\mathrm{H}]^{+}=788.13,[\mathrm{M}+\mathrm{Na}]^{+}=810.09$.

Compound 97. Starting from 86 (0.68 g, $0.87 \mathrm{mmol})$, compound 97 was obtained (0.85 mmol, 98\%). Yellow oil. ${ }^{1} \mathrm{H}$ NMR 
(300 MHz, $\left.\mathrm{CD}_{3} \mathrm{OD}\right) \delta 8.53(\mathrm{~s}, 1 \mathrm{H}, \mathrm{CH}$ triazole), 6.98 (s, 3H, Ar), 4.79 (dd, $2 \mathrm{H}, J=5.04$ and $4.62 \mathrm{~Hz}, \mathrm{OCH}_{2}$ triazole), 4.04 (dd, $2 \mathrm{H}$, $J=5.25$ and $4.62 \mathrm{~Hz}, \mathrm{NCH}_{2}$ triazole), 3.79-3.64 (m, 16H, PEG), $3.23,3.16\left(\mathrm{~d}, 4 \mathrm{H}, J=21.93 \mathrm{~Hz}, \mathrm{CH}_{2} \mathrm{PO}(\mathrm{OH})_{2}\right), 2.63(\mathrm{t}, 2 \mathrm{H}, J=6.12$ $\left.\mathrm{Hz}, \mathrm{CH}_{2} \mathrm{COOH}\right) ;{ }^{13} \mathrm{C}$ NMR (75 MHz, CD $\left.{ }_{3} \mathrm{OD}\right) \delta .173 .7(\mathrm{COOH})$, 158.7 (C Ar next to triazole), 141.2 (C triazole), $135.5(J=12 \mathrm{~Hz}$, $\mathrm{C}$ Ar next to $\left.\mathrm{CH}_{2} \mathrm{PO}(\mathrm{OH})_{2}\right), 129.0(\mathrm{CH}$ triazole $), 126.1(\mathrm{~J}=6.00 \mathrm{~Hz}$, $\mathrm{CH}$ Ar next to $\left.\mathrm{CH}_{2} \mathrm{PO}(\mathrm{OH})_{2}\right), 115.9$ ( $\mathrm{CH}$ Ar next to triazole), 71.2 (PEG), 71.1 (PEG), 71.0 (PEG), 69.0 ( $\mathrm{NCH}_{2} \mathrm{CH}_{2} \mathrm{O}$ next to triazole), $67.4\left(\mathrm{OCH}_{2}\right.$ next to triazole), $60.3\left(\mathrm{NCH}_{2} \mathrm{CH}_{2} \mathrm{O}\right), 54.1\left(\mathrm{NCH}_{2}-\right.$ $\left.\mathrm{CH}_{2} \mathrm{O}\right), 52.2\left(\mathrm{CH}_{2} \mathrm{CH}_{2} \mathrm{COOH}\right), 35.6\left(\mathrm{CH}_{2} \mathrm{COOH}\right), 36.0,34.3(\mathrm{~J}=$ $\left.133.09 \mathrm{~Hz}, \mathrm{CH}_{2} \mathrm{PO}(\mathrm{OH})_{2}\right)$; ${ }^{31} \mathrm{P} \mathrm{NMR}\left(81 \mathrm{MHz}, \mathrm{CDCl}_{3}\right) \delta 25.77 ; \mathrm{MS}$ (MALDI-TOF) $m / z$ calculated for $\mathrm{C}_{22} \mathrm{H}_{35} \mathrm{~N}_{3} \mathrm{O}_{13} \mathrm{P}_{2}$ 611.16, obtained $[\mathrm{M}+\mathrm{H}]^{+}=612.12$.

Compound 98. Starting from $87(0.53 \mathrm{~g}, 0.56 \mathrm{mmol})$, compound 98 was obtained $(0.54 \mathrm{mmol}, 97 \%)$ as a Burgundy oil. ${ }^{1} \mathrm{H}$ NMR (300 MHz, CD $\left.3 \mathrm{OD}\right) \delta 8.35(\mathrm{~s}, 1 \mathrm{H}, \mathrm{CH}$ triazole), $6.95(\mathrm{bs}, 3 \mathrm{H}$, $\mathrm{Ar}), 5.28\left(\mathrm{~s}, 2 \mathrm{H}, \mathrm{OCH}_{2}\right.$ triazole), $4.71(\mathrm{dd}, 2 \mathrm{H}, J=4.80$ and $4.83 \mathrm{~Hz}$, $\mathrm{NCH}_{2}$ triazole), 3.99 (dd, $2 \mathrm{H}, J=5.04$ and $4.80 \mathrm{~Hz}, \mathrm{NCH}_{2} \mathrm{CH}_{2} \mathrm{O}$ triazole), 3.82-3.66 (m, 26H, PEG), 3.20, 3.13 (d, $4 \mathrm{H}, J=21.48 \mathrm{~Hz}$, $\left.\mathrm{CH}_{2} \mathrm{PO}(\mathrm{OH})_{2}\right), 2.65\left(\mathrm{dd}, 2 \mathrm{H}, J=6.15\right.$ and $\left.6.12 \mathrm{~Hz}, \mathrm{CH}_{2} \mathrm{COOH}\right) ;{ }^{13} \mathrm{C}$ NMR (75 MHz, CD 3 OD) $\delta 173.7(\mathrm{COOH}), 158.9(J=2.73 \mathrm{~Hz}, \mathrm{C} \mathrm{Ar}$ next to triazole), $135.7\left(J=9.27 \mathrm{~Hz}, \mathrm{C}\right.$ Ar next to $\left.\mathrm{CH}_{2} \mathrm{PO}(\mathrm{OH})_{2}\right), 153.2$ (C triazole), $126.0\left(J=6.54 \mathrm{~Hz}, \mathrm{CH}\right.$ Ar next to $\left.\mathrm{CH}_{2} \mathrm{PO}(\mathrm{OH})_{2}\right), 125.4$ (CH triazole), 115.9 (CH Ar next to triazole), 71.3 (PEG), 71.1 (PEG), $69.3\left(\mathrm{NCH}_{2} \mathrm{CH}_{2} \mathrm{O}\right.$ next to triazole $), 67.4\left(\mathrm{OCH}_{2}\right.$ next to triazole), 60.7 $\left(\mathrm{NCH}_{2} \mathrm{CH}_{2} \mathrm{O}\right), \quad 53.6\left(\mathrm{NCH}_{2} \mathrm{CH}_{2} \mathrm{O}\right), \quad 52.2 \quad\left(\mathrm{CH}_{2} \mathrm{CH}_{2} \mathrm{COOH}\right), \quad 35.6$ $\left(\mathrm{CH}_{2} \mathrm{COOH}\right), 36.3,34.5\left(\mathrm{~J}=133.0 \mathrm{~Hz}, \mathrm{CH}_{2} \mathrm{PO}(\mathrm{OH})_{2}\right) ;{ }^{31} \mathrm{P}$ NMR $\left(81 \mathrm{MHz}, \mathrm{CDCl}_{3}\right) \delta$ 25.79; MS (MALDI-TOF) $\mathrm{m} / \mathrm{z}$ calculated for $\mathrm{C}_{30} \mathrm{H}_{51} \mathrm{~N}_{3} \mathrm{O}_{17} \mathrm{P}_{2}$ 787.26, obtained $[\mathrm{M}+\mathrm{H}]^{+}=788.12$.

Compound 99. Starting from 90 ( $0.37 \mathrm{~g}, 0.84 \mathrm{mmol})$, compound 99 was obtained (0.69 mmol, 83\%). Orange oil. ${ }^{1} \mathrm{H}$ NMR $\left(300 \mathrm{MHz}, \mathrm{CDCl}_{3}\right) \delta 10.34\left(\mathrm{~s}, 3 \mathrm{H}, \mathrm{PO}(\mathrm{OH})_{2}, \mathrm{COOH}\right), 3.78-3.52$ (m, 12H, PEG), 2.50 (qt, $\left.2 \mathrm{H}, J=4.38 \mathrm{~Hz}, \mathrm{CH}_{2} \mathrm{COOH}\right), 2.17(\mathrm{~m}, 2 \mathrm{H}$, $\left.\mathrm{CH}_{2} \mathrm{PO}(\mathrm{OH})_{2}\right) ;{ }^{13} \mathrm{C}$ NMR (75 $\left.\mathrm{MHz}, \mathrm{CDCl}_{3}\right) \delta 172.1(\mathrm{COOH}), 70.5$ (PEG), 70.4 (PEG), 70.3 (PEG), 70.2 (PEG), 69.9 (PEG), 66.4 $\left(\mathrm{CH}_{2} \mathrm{CH}_{2} \mathrm{COOH}\right), 51.7\left(\mathrm{~J}=5.45 \mathrm{~Hz}, \mathrm{OCH}_{2} \mathrm{CH}_{2} \mathrm{PO}(\mathrm{OH})_{2}\right), 34.7$ $\left(\mathrm{CH}_{2} \mathrm{COOH}\right), 28.0,26.2\left(\mathrm{~J}=135.27 \mathrm{~Hz}, \mathrm{CH}_{2} \mathrm{PO}(\mathrm{OH})_{2}\right) ;{ }^{31} \mathrm{P} \mathrm{NMR}$ $\left(81 \mathrm{MHz}, \mathrm{CDCl}_{3}\right) \delta$ 33.18; MS (MALDI-TOF) $\mathrm{m} / \mathrm{z}$ calculated for $\mathrm{C}_{11} \mathrm{H}_{23} \mathrm{O}_{9} \mathrm{P} 330.10$, obtained $[\mathrm{M}+\mathrm{H}]^{+}=331.11,[\mathrm{M}+\mathrm{Na}]^{+}=353.10$.

Compound 100. Starting from 91 (0.09 g, $0.14 \mathrm{mmol})$, compound 100 was obtained (0.14 mmol, 99\%). Orange oil. ${ }^{1} \mathrm{H}$ NMR $\left(300 \mathrm{MHz}, \mathrm{CDCl}_{3}\right) \delta 9.61\left(\mathrm{~s}, 3 \mathrm{H}, \mathrm{PO}(\mathrm{OH})_{2}, \mathrm{COOH}\right), 3.84-3.42$ $(\mathrm{m}, 32 \mathrm{H}, \mathrm{PEG}), 2.55\left(\mathrm{~m}, 2 \mathrm{H}, \mathrm{CH}_{2} \mathrm{COOH}\right), 2.26(\mathrm{~m}, 2 \mathrm{H}$, $\left.\mathrm{CH}_{2} \mathrm{PO}(\mathrm{OH})_{2}\right) ;{ }^{13} \mathrm{C}$ NMR (75 MHz, $\left.\mathrm{CDCl}_{3}\right) \delta 172.1(\mathrm{COOH}), 70.3$ (PEG), 70.2 (PEG), 70.1 (PEG), 69.9 (PEG), 69.6 (PEG), 66.4 $\left(\mathrm{CH}_{2} \mathrm{CH}_{2} \mathrm{COOH}\right), 51.7\left(\mathrm{OCH}_{2} \mathrm{CH}_{2} \mathrm{PO}(\mathrm{OH})_{2}\right), 34.7\left(\mathrm{CH}_{2} \mathrm{COOH}\right)$, 28.1, 26.3 $\left(J=135.27 \mathrm{~Hz}, C_{2} \mathrm{PO}(\mathrm{OH})_{2}\right) ;{ }^{31} \mathrm{P} \mathrm{NMR}(81 \mathrm{MHz}$, $\left.\mathrm{CDCl}_{3}\right) \delta$ 29.03; MS (MALDI-TOF) $\mathrm{m} / z$ calculated for $\mathrm{C}_{19} \mathrm{H}_{39} \mathrm{O}_{13} \mathrm{P}$ 506.21, obtained $[\mathrm{M}+\mathrm{H}]^{+}=507.15,[\mathrm{M}+\mathrm{Na}]^{+}=529.12$.

\section{Acknowledgements}

We thank the CNRS, UDS and the French Ministry of Research (fellowship to A. Walter) for financial support. This work was also supported by the Région Alsace (fellowships to A. Parat, C. Bordeianu), by the University of Mons, Belgium (fellowship to C. Bordeianu), by the European Union (European Regional Development Fund - ERDF) in the framework of the program “Nano@matrix” INTERREG IV Upper Rhine Valley. "Transcending borders with every project" (fellowships to A. Garofalo and J. Jouhannaud) and by the ANR (fellowship to C. Ghobril). We also thank Emilie Voirin and Emilie Couzigné for technical assistance and Dr Jean-Marc Strub for Mass Spectrometry measurements.

\section{Notes and references}

1 B. L. Cushing, V. L. Kolesnichenko and C. J. O'Connor, Chem. Rev., 2004, 104, 3893; M. C. Daniel and D. Astruc, Chem. Rev., 2004, 104, 293.

2 (a) R. Frantz, J.-O. Durand, G. F. Lanneau, J.-C. Jumas, J. Olivier-Fourcade, J.-M. Cretin and M. Persin, Eur. J. Inorg. Chem., 2002, 1088; (b) G. P. Holland, R. Sharma, J. O. Agola, S. Amin, V. C. Solomon, P. Singh, D. A. Buttry and J. L. Yarger, Chem. Mater., 2007, 19, 2519; (c) M. N. Tchoul, S. P. Fillery, H. Koerner, L. F. Drummy, F. T. Oyerokun, P. A. Mirau, M. F. Durstock and R. A. Vaia, Chem. Mater., 2010, 22, 1749; (d) C. A. Traina and J. Schwartz, Langmuir, 2007, 23, 9158; (e) G. Chouhan, D. S. Wang and H. Alper, Chem. Commun., 2007, 4809; $(f)$ A. Hu, G. T. Yee and W. Lin, J. Am. Chem. Soc., 2005, 127, 12486; (g) M. A. White, J. A. Johnson, J. T. Koberstein and N. J. Turro, J. Am. Chem. Soc., 2006, 128, 11356; $(h)$ C. Yee, G. Kataby, A. Ulman, T. Prozorov, H. White, A. King, M. Rafailovich, J. Sokolov and A. Gedanken, Langmuir, 1999, 15, 7111.

3 J. Kim, Y. Piao and T. Hyeon, Chem. Soc. Rev., 2009, 38, 372.

4 G. F. Goya, L. Asin and M. R. Ibarra, Int. J. Hyperthermia, 2013, 1-9, DOI: 10.3109/02656736.2013.838646.

5 S. Vizirianakis and D. G. Fatouros, Adv. Drug Delivery Rev., 2012, 64, 1359.

6 A. Meerasa, J. G. Huang and F. X. Gu, Curr. Drug Delivery, 2011, 8, 290.

7 (a) A. Karimi, B. Denizot, F. Hindre, R. Filmon, J.-M. Greneche, S. Laurent, T. J. Daou, S. Begin-Colin and J. J. Le Jeune, J. Nanopart. Res., 2010, 12, 1239; (b) D. Portet, B. Denizot, E. Rump, J. J. Lejeune and P. Jallet, J. Colloid Interface Sci., 2001, 238, 37.

8 (a) V. Andre, H. Lahrache, S. Robin and G. Rousseau, Tetrahedron, 2007, 63, 10059; (b) R. J. Cohen, D. L. Fox, J. F. Eubank and R. N. Salvatore, Tetrahedron Lett., 2003, 44, 8617; (c) Z. Hasnik, R. Pohl and M. Hocek, Tetrahedron Lett., 2010, 51, 2464; (d) S. A. Snyder, S. P. Breazzano, A. G. Ross, Y. Q. Lin and A. L. Zografos, J. Am. Chem. Soc., 2009, 131, 1753.

9 (a) L. B. Han, F. Mirzaei, C. Q. Zhao and M. Tanaka, J. Am. Chem. Soc., 2000, 122, 5407; (b) L. B. Han and M. Tanaka, J. Am. Chem. Soc., 1996, 118, 1571; (c) C. Q. Zhao, L. B. Han, M. Goto and M. Tanaka, Angew. Chem., Int. Ed., 2001, 40, 1929. 10 (a) F. Alonso, I. P. Beletskaya and M. Yus, Chem. Rev., 2004, 104, 3079; (b) N. S. Goulioukina, T. M. Dolgina, I. P. Beletskaya, 
J. C. Henry, D. Lavergne, V. Ratovelomanana-Vidal and J. P. Genet, Tetrahedron: Asymmetry, 2001, 12, 319.

11 (a) L. B. Han, C. Zhang, H. Yazawa and S. Shimada, J. Am. Chem. Soc., 2004, 126, 5080; (b) Y. X. Gao, G. Wang, L. Chen, P. X. Xu, Y. F. Zhao and Y. B. Zhou, J. Am. Chem. Soc., 2009, 131, 7956.

12 (a) T. Hirao, T. Masunaga, Y. Ohshiro and T. Agawa, Tetrahedron Lett., 1980, 21, 3595; (b) T. Hirao, T. Masunaga, Y. Ohshiro and T. Agawa, Synthesis, 1981, 56; (c) T. Hirao, T. Masunaga, N. Yamada, Y. Ohshiro and T. Agawa, Bull. Chem. Soc. Jpn., 1982, 55, 909.

13 D. Enders, A. Saint-Dizier, M. I. Lannou and A. Lenzen, Eur. J. Org. Chem., 2006, 29.

14 A. N. Pudovik and I. V. Konovalova, Synthesis, 1979, 81.

15 (a) A. Michaelis and R. Kaehne, Chem. Ber., 1898, 31, 1048; (b) A. K. Bhattacharya and G. Thyagarajan, Chem. Rev., 1981, 81, 415.

16 G. G. Rajeshwaran, M. Nandakumar, R. Sureshbabu and A. K. Mohanakrishnan, Org. Lett., 2011, 13, 1270.

17 R. J. Barney, R. M. Richardson and D. F. Wiemer, J. Org. Chem., 2011, 76, 2875.

18 Dendrimers: towards catalytic, material and biomedical uses, ed. A.-M. Caminade, C.-O. Turrin, R. Laurent, A. Ouali and B. Delavaux-Nicot, John Wiley \& sons, 2011.

19 O. Rolland, C. O. Turrin, A.-M. Caminade and J.-P. Majoral, New J. Chem., 2009, 33, 1809; A. J. L. Villaraza, A. Bumb and M. W. Brechbiel, Chem. Rev., 2010, 110, 2921.

20 A. Bertin, J. Steibel, A.-I. Michou-Gallani, J.-L. Gallani and D. Felder-Flesch, Bioconjugate Chem., 2009, 20, 760.

21 (a) T. J. Daou, G. Pourroy, J.-M. Greneche, A. Bertin, D. FelderFlesch and S. Begin-Colin, Dalton Trans., 2009, 4442; (b) C. Boyer, V. Bulmus, P. Priyanto, W. Y. Teoh, R. Amal and T. P. Davis, J. Mater. Chem., 2009, 19, 111; (c) B. Basly, D. FelderFlesch, P. Perriat, G. Pourroy and S. Begin-Colin, Contrast Media Mol. Imaging, 2011, 6(3), 132; (d) S. Chandra, S. Mehta, S. Nigam and D. Bahadur, New J. Chem., 2010, 34, 648.

22 (a) B. Basly, G. Popa, S. Fleutot, B. Pichon, A. Garofalo, C. Ghobril, C. Billotey, A. Berniard, P. Bonazza, H. Martinez, P. Perriat, D. Felder-Flesch and S. Begin-Colin, Dalton Trans., 2013, 42, 2146; (b) G. Lamanna, A. Garofalo, G. Popa, C. Wilhelm, S. Bégin-Colin, D. Felder-Flesch, F. Gazeau, A. Bianco and C. Ménard-Moyon, Nanoscale, 2013, 5, 4412; (c) C. Ghobril, G. Popa, A. Parat, C. Billotey,
P. Bonazza, J. Taleb, S. Begin-Colin and D. Felder-Flesch, Chem. Commun., 2013, 49, 9158; (d) P. Chevallier, A. Walter, A. Garofalo, I. Veksler, J. Lagueux, S. Begin-Colin, D. FelderFlesch and M.-A. Fortin, J. Mater. Chem. B, 2014, 2, 1779.

23 A. Hofmann, S. Thierbach, A. Semisch, A. Hartwig, M. Taupitz and E. Rühl, J. Mater. Chem., 2010, 20, 7842.

24 (a) T. J. Daou, J. M. Greneche, G. Pourroy, S. Buathong, A. Derory, C. Ulhaq-Bouillet, B. Donnio, D. Guillon and S. Begin-Colin, Chem. Mater., 2008, 20, 5869; (b) T. J. Daou, S. Begin-Colin, J.-M. Greneche, F. Thomas, A. Derory, P. Bernhardt, P. Legare and G. Pourroy, Chem. Mater., 2007, 19, 4494.

25 B. Basly, D. Felder-Flesch, P. Perriat, C. Billotey, J. Taleb, G. Pourroy and S. Begin-Colin, Chem. Commun., 2010, 46, 985.

26 (a) G. Lamanna, M. Kueny-Stotz, H. Mamlouk-Chaouachi, A. Bertin, B. Basly, C. Ghobril, C. Billotey, I. Miladi, G. Pourroy, S. Begin-Colin and D. Felder-Flesch, Biomaterials, 2011, 32, 8562; (b) M. Kueny-Stotz, H. Mamlouk-Chaouachi and D. Felder-Flesch, Tetrahedron Lett., 2011, 52, 2906.

27 C. Gentilini, M. Boccalon and L. Pasquato, Eur. J. Org. Chem., 2008, 3308.

28 C. E. McKenna, M. T. Higa, N. H. Cheung and M. C. McKenna, Tetrahedron Lett., 1977, 155.

29 D. Schrigten, H.-J. Breyholz, S. Wagner, S. Hermann, O. Schober, M. Schäfers, G. Haufe and K. Kopka, J. Med. Chem., 2012, 55, 223.

30 J. W. Lee, B.-K. Kim, H. J. Kim, S. C. Han, W. S. Shin and S.-H. Jin, Macromolecules, 2006, 39, 2418.

31 (a) A. Markovac and M. P. Lamontagne, J. Med. Chem., 1980, 23, 1198; (b) S. V. Bhosale, M. B. Kalyankar, S. J. Langford, S. V. Bhosale and R. F. Oliver, Eur. J. Org. Chem., 2009, 4128; (c) E. Diez-Barra, J. C. Garcia-Martinez, S. Merino, R. del Rey, J. Rodriguez-Lopez, P. Sanchez-Verdu and J. Tejeda, J. Org. Chem., 2001, 66, 5664.

32 T. Shiraki, A. Dawn, Y. Tsuchiya and S. Shinkai, J. Am. Chem. Soc., 2010, 132, 13928.

33 A. Cappelli, S. Galeazzi, G. Guiliani, M. Anzini, M. Grassi, R. Lapasin, G. Grassi, R. Farra, B. Dapas, M. Aggravi, A. Donati, L. Zetta, A. C. Boccia, F. Bertini, F. Samperi and S. Vomero, Macromolecules, 2009, 42, 2368.

34 H. Herzner and H. Kunz, Carbohydr. Res., 2007, 342, 541.

35 H. E. Gottlieb, V. Kotlyar and A. Nudelman, J. Org. Chem., 1997, 62, 7512 . 